AperTO - Archivio Istituzionale Open Access dell'Università di Torino

Post-translational inhibition of YAP oncogene expression by 4-hydroxynonenal in bladder cancer cells

This is the author's manuscript

Original Citation:

Availability:

This version is available http://hdl.handle.net/2318/1718896

since 2019-12-11T09:29:28Z

Published version:

DOI:10.1016/j.freeradbiomed.2019.06.009

Terms of use:

Open Access

Anyone can freely access the full text of works made available as "Open Access". Works made available under a Creative Commons license can be used according to the terms and conditions of said license. Use of all other works requires consent of the right holder (author or publisher) if not exempted from copyright protection by the applicable law. 


\section{Post-translational inhibition of YAP oncogene expression by 4-hydroxynonenal in bladder cancer cells.}

Running Title: HNE post-translationally inhibits YAP expression in bladder cancer cells

Cucci Marie Angele ${ }^{\mathrm{a}, 1}$, Compagnone Alessandra ${ }^{\mathrm{b}, 1}$, Daga Martina ${ }^{\mathrm{a}}$, Grattarola Margherita ${ }^{\mathrm{a}}$, Ullio Chiara $^{\mathrm{a}}$, Roetto Antonella ${ }^{\mathrm{a}}$, Palmieri Antonietta ${ }^{\mathrm{a}}$, Rosa Arianna Carolina ${ }^{\mathrm{c}}$, Argenziano Monica ${ }^{\mathrm{c}}$, Cavalli Roberta ${ }^{\mathrm{c}}$, Simile Maria Maddalena ${ }^{\mathrm{d}}$, Pascale Rosa Maria ${ }^{\mathrm{d}}$, Dianzani Chiara ${ }^{\mathrm{c}}$, Barrera Giuseppina $^{\mathrm{a}, 2}$, Pizzimenti Stefania ${ }^{\mathrm{a}, 2, *}$

${ }^{a}$ Department of Clinical and Biological Sciences, University of Turin, Corso Raffaello 30, 10125 Turin (CMA, DM, BG, SP), and Regione Gonzole 10, 10043 Orbassano (Turin) (RA, PA), Italy.

${ }^{\mathrm{b}}$ Department of Oncology, University of Turin, Via Michelangelo 27, 10125 Turin, Italy.

${ }^{c}$ Department of Drug Science and Technology, University of Turin, Via Pietro Giuria 9, 10125 Turin, Italy.

${ }^{\mathrm{d} D e p a r t m e n t ~ o f ~ C l i n i c a l ~ a n d ~ E x p e r i m e n t a l ~ M e d i c i n e, ~ D i v i s i o n ~ o f ~ E x p e r i m e n t a l ~ P a t h o l o g y ~ a n d ~}$ Oncology, University of Sassari, Sassari, Italy

${ }^{1}$ These Authors contributed equally to this work.

${ }^{2}$ Co-last authors.

*Corresponding author: Stefania Pizzimenti; Department of Clinical and Biological Sciences, University of Turin; Corso Raffaello 30, 10125 Torino, Italy; Fax +39-011-6707753; e-mail: stefania.pizzimenti@unito.it

Keywords: YAP; Hippo signaling pathway; 4-hydroxynonenal; cell proliferation; apoptosis; cell cycle; migration; invasion; angiogenesis; N-acetylcysteine; GSH; p-YAP ser127; p-YAP ser387; ubiquitination; proteasome; transfection; T24 bladder cancer cells; CRL2335 breast cancer cells; A375 melanoma cells. 


\begin{abstract}
The transcriptional regulator YAP plays an important role in cancer progression and is negatively controlled by the Hippo pathway. YAP is frequently overexpressed in human cancers, including bladder cancer. Interestingly, YAP expression and activity can be inhibited by pro-oxidant conditions; moreover, YAP itself can also affect the cellular redox status through multiple mechanisms. 4-Hydroxynonenal (HNE), the most intensively studied end product of lipid peroxidation, is a pro-oxidant agent able to deplete GSH and has an anti-tumoral effect by affecting multiple signal pathways, including the down-regulation of oncogene expressions. These observations prompted us to investigate the effect of HNE on YAP expression and activity. We demonstrated that HNE inhibited YAP expression and its target genes in bladder cancer cells through a redox-dependent mechanism. Moreover, the YAP down-regulation was accompanied by an inhibition of proliferation, migration, invasion, and angiogenesis, as well as by an accumulation of cells in the G2/M phase of cell cycle and by an induction of apoptosis. We also established the YAP role in inhibiting cell viability and inducing apoptosis in HNE-treated cells by using an expression vector for YAP. Furthermore, we identified a post-translational mechanism for the HNEinduced YAP expression inhibition, involving an increase of YAP phosphorylation and ubiquitination, leading to proteasomal degradation. Our data established that HNE can posttranslationally down-regulate YAP through a redox-dependent mechanism and that this modulation can contribute to determining the specific anti-cancer effects of HNE.
\end{abstract}




\section{Introduction}

Yes-associated protein (YAP) is a transcriptional co-activator belonging to the Hippo tumorsuppressor pathway. This signaling pathway plays a key role as a regulator of organ size, and it has been involved in the control of cell proliferation, apoptosis, and differentiation [1]. Hippo pathway consists of a core kinase cascade in which the Mammalian Ste20-like kinases 1/2 (MST1/2) phosphorylate and activate the Large Tumor Suppressor 1/2 (LATS1/2). When the pathway is active, Lats $1 / 2$ can phosphorylate and inhibit YAP, one of the major effectors of this signaling cascade. YAP can be phosphorylated at multiple sites. When the Ser 127 is phosphorylated, this results in YAP binding to the adapter protein 14 ï $3 \ddot{3} 3$, leading to its cytoplasmic retention [2]. In addition to the inhibition of nuclear YAP translocation, phosphorylation by Lats1/2 and other kinases through the phosphorylation in Ser 381/384/387 also suppresses YAP activity by inducing proteasomal degradation [3]. On the contrary, when the Hippo cascade is inactive, the unphosphorylated form of YAP can translocate into the nucleus and form complexes mainly with the transcription family TEAD (TEA domain family member), leading to the expression of target genes involved in proliferation, cell survival, migration, epithelial-mesenchymal transition (EMT), and angiogenesis; such as the growth factor CTGF (connective tissue growth factor), survivin, which is able to affect cell cycle progression and to inhibit apoptosis, the c-Myc oncogene, and the angiogenic factor CYR61 (angiogenetic inducer rich in cysteine 61) [4-7].

Hippo pathway deregulation occurs in many human cancers and its effector YAP was initially identified as an oncogene in a variety of tumors, where it was shown to promote growth factor-independent proliferation, EMT, survival, and stemness [8-10]. Frequently correlated with a poor prognosis and tumor progression, high expression of YAP has been observed in numerous malignancies [11-12], including bladder cancer [13]. Moreover, we have recently demonstrated that constitutive expression and activation of YAP is inversely correlated with ñin vitroò and ñn vivoò cisplatin sensitivity of urothelial carcinoma cells [14].

Interestingly, it has been demonstrated that YAP expression can be regulated by the cellular oxidative redox state in HepG2 hepatocarcinoma cancer cells [15]; in particular, the use of diethyl maleate (DEM), a pro-oxidant agent able to deplete GSH, inhibited YAP expression; whereas, the pre-pretreatment with the antioxidant $\mathrm{N}$-acetylcysteine (NAC), an aminothiol and synthetic precursor of intracellular cysteine and GSH, substantially abolished the DEM action on YAP expression. These authors identified the mechanisms of this redox-dependent regulation, consisting in the inactivation of the GABP transcription factor, an Ets family member, able to induce the YAP transcription [15]. Our previous results also confirmed that the treatment with buthionine 
sulfoximine (BSO), a GSH-depleting agent, reduced the YAP expression in bladder cancer cells [16].

On the other way round, it has been demonstrated that YAP itself can affect the cellular redox status with multiple mechanisms. For instance, YAP can also bind the transcription factor FoxO1, and the YAP-FoxO1 complex can bind the promoters of antioxidant genes, such as catalase and manganese superoxide dismutase (MnSOD), stimulating their transcription [17]. Moreover, the interaction with the transcription factor Pitx 2 has also been proposed as a mechanism for the YAP inducing antioxidant genes in cardiomyocytes [18]. Recently, we have demonstrated a cross-talk between YAP and the transcription factor Nrf2 (NF-E2-related factor 2), the master regulator of antioxidant and cytoprotective systems. In bladder cancer, the two genes cooperate in maintaining the antioxidant potential, which plays an important role in chemoresistance [16].

This interplay between the transcriptional co-activator YAP and the redox cellular state prompted us to investigate a possible role of 4-hydroxynonenal (HNE), the most intensively studied end product of lipid peroxidation [19-20], in affecting YAP activity. Indeed, it is well known that HNE, as DEM, is a pro-oxidant agent, able to deplete GSH in several cells and tissues [21-23]. Moreover, and more interestingly, at micromolar concentrations, similar to those found in human plasma and tissues [20], HNE can inhibit cell proliferation, induce apoptosis and/or differentiation $[19,24]$, inhibit cell adhesion [25], and angiogenesis [26] in a variety of both hematological and solid tumors [27]. It has been shown that HNE elicits its biological effect by affecting multiple signal pathways, also through the modulation of the expression of a broad range of key genes, including oncogenes such as c-myc [28-31], c-myb [32], cyclin D1/D2 /A [33-34], telomerase reverse transcriptase hTERT $[31,35]$.

In consideration of these characteristics, this experimental work aimed to verify if $\mathrm{HNE}$ treatments could affect YAP expression and its activity in YAP over-expressed bladder cancer cells and whether this modulation could be redox-dependent. Furthermore, the mechanisms of YAP expression inhibition in HNE-treated bladder cancer cells were also investigated.

\section{Materials and Methods}

\section{Cells, culture conditions and HNE preparation}

Human bladder cancer T24 cells, human breast cancer CRL-2335 cells, and human melanoma A375 cells were purchased from the American Type Culture Collection (ATCC, Manassas, VA, USA). Human bladder 253J, 253J B-V, and UM-UC-3 cell lines were kindly provided by Dr. Colin 
Dinney (MD Anderson Cancer Center). UM-UC-3 were cultured in Eagle's Minimum Essential Medium, while all the others in RPMI 1640. Both media were supplemented with $10 \%$ FBS, 100 units $/ \mathrm{ml}$ penicillin and $100 \mathrm{gg} / \mathrm{ml}$ streptomycin in a $5 \% \mathrm{CO} 2,37^{\circ} \mathrm{C}$ incubator.

Human Umbilical Vein Endothelial Cells (HUVECs) were isolated from human umbilical veins by trypsin treatment (1\%) and cultured in M199 medium, with the addition of $20 \%$ FCS, $100 \mathrm{U} / \mathrm{ml}$ penicillin, $100 \mathrm{\varepsilon g} / \mathrm{ml}$ streptomycin, $5 \mathrm{UI} / \mathrm{ml}$ heparin, $12 \mathrm{\varepsilon g} / \mathrm{ml}$ bovine brain extract, and $200 \mathrm{mM}$ glutamine. HUVECs were grown to confluence in flasks and used at passages two through five. For the HNE-treatment, the aldehyde was purchased from Calbiochem-Merk (393204) (Milan, Italy) and it was prepared as follows: HNE was dissolved in ethanol that was evaporated through a gentle flow of $\mathrm{N}_{2}$ and subsequently resuspended in sterile phosphate-buffered saline, 1x concentrate pH 7.4 (1xPBS). The concentration was measured by spectrophotometer recording the absorbance of an aliquot of HNE diluted 1:200 in water at $223 \mathrm{~nm}\left(\mathrm{U}^{\circ}=13,7501 / \mathrm{mol} / \mathrm{cm}\right)$.

NAC, DEM, and the proteasome inhibitor MG132 were purchased from Sigma-Aldrich (Milan, Italy).

\section{Lysate preparation and western blot analysis}

Lysate preparation and western blot (WB) analysis were performed as previously described [16], with minor modification. Briefly, cells were seeded in 6-well plates (250,000 cells/well) and treated as indicated in the ñResultsò section. Subsequently, the cells were harvested, washed once in icecold $1 \times \mathrm{PBS}$; resuspended in a lysis buffer composed of $20 \mathrm{mM}$ Trisï $\mathrm{HCl}, \mathrm{pH}$ 7.4, $150 \mathrm{mM} \mathrm{NaCl}, 5$ mM EDTA, $1 \%$ v/v Triton X-100, phosphatase (Sigmaï Aldrich P2850), and protease (Sigmaï Aldrich P8340) inhibitor cocktails; and incubated for $30 \mathrm{~min}$ at $4{ }^{\circ} \mathrm{C}$. Samples were centrifuged at $12,000 \mathrm{rpm}$ for $25 \mathrm{~min}$ at $4{ }^{\circ} \mathrm{C}$, the supernatants were collected, and the protein concentration was determined using a commercially available kit (Bio-Rad Laboratories, Segrate, MI, Italy). Western blot analysis was performed using home-made $7.5 \%$ SDSï polyacrylamide gels or 5 Ï $15 \%$ gradient SDSï polyacrylamide precast gels (Bio-Rad Laboratories). 20-40 عg of proteins were mixed with $20 \varepsilon 1$ of Laemmli sample buffer (Bio-Rad Laboratories 161-0737), containing 10\% 2mercaptoethanol, boiled for $5 \mathrm{~min}$, and loaded onto the gels.

The run was performed at the constant voltage of $100 \mathrm{~V}$. Afterwards, proteins from the gel were transferred to nitrocellulose membranes with the Trans-Blot Turbo Transfer System (Bio-Rad Laboratories). The membranes were subsequently blocked for $1 \mathrm{~h}$ with $5 \%$ nonfat dry milk dissolved in TBSï Tween 20, incubated overnight at $4{ }^{\circ} \mathrm{C}$ with primary antibodies, washed three times with TBSï Tween 20, and incubated with HRP-conjugated secondary antibodies for $1 \mathrm{~h}$ at room temperature. Antibodies used were as follows: cleaved Poly (ADP-ribose) polymerase 
(PARP) Asp214 (\#9541), total PARP (9542S), glyceraldehyde 3 phosphate dehydrogenase (GAPDH) (\#5174), p-YAP ser 387 (D1E7Y), and p-YAP ser 127 (D9W2I) from Cell Signaling (Boston, MA, USA); YAP (sc-15407), survivin (sc-17779), ubiquitin (P4D1) (sc-8017), Cyr61 (sc13100), and MnSOD (sc-30080), vascular endothelial growth factor (VEGF) (sc-152) from Santa Cruz (Dallas, TX, USA); б-actin, clone A1978 from Sigma-Aldrich; Ǔtubulin (04-1117) from Millipore (Billerica, MA, USA). The detection of the bands was carried out after reaction with chemiluminescence reagents (ECL Prime Western Blotting RPN2236, Sigma-Aldrich), through ýlm (Santa Cruz Biotechnology sc-201697) autoradiography or with a camera imaging system (Imagequant LAS 4000, GE Healthcare, Little Chalfont, UK).

\section{Immunofluorescence staining of YAP and Ki-67 proteins}

Immunofluorescence analysis was performed as previously described [16], with slight modifications. Briefly, T24 cells $\left(5 \times 10^{4}\right)$ were plated into the channels of a $\mu$ ï Slide VI0.4 (Ibidi, Giemme Snc, Milano, Italy). After treatments, cells were fixed for $15 \mathrm{~min}$ in $4 \%$ paraformaldehyde and permeabilized with $1 \%$ Triton X-100 for 30 min at room temperature and washed with 1xPBS. Then, the cells were incubated with $1 \%$ BSA in $1 x$ PBS for 30 min at room temperature, after which they were incubated for $1 \mathrm{~h}$ at room temperature with the primary monoclonal antibody against YAP (sc15407) or Ki67 (MIB-1, Dako Agilent Technologies Italia S.p.A., Italy) in 1\% BSA dissolved in 1 xPBS. The cells were subsequently washed, incubated for $1 \mathrm{~h}$ at room temperature with the secondary FITC-conjugated antibody (1:100 in 0.1\%BSA in 1xPBS; Sigma-Aldrich) for YAP staining, and with Cy3-conjugated antibody $(1: 1000$ in $0.1 \%$ BSA in 1xPBS; GE Healthcare, USA) for Ki67 staining. Nuclei were stained by using 4,6-diamino-2-phenylindole (DAPI) in YAPstained cells, and Hoechst 33342 (B-2883, Sigma-Aldrich) in Ki67-stained cells. After washing with 1xPBS, cover glasses were mounted with $50 \%$ glycerol, $15 \mathrm{mM} \mathrm{NaN3}$ in 1xPBS. The cells were then analyzed under a fluorescence microscope (Axiovert 35; Carl Zeiss MicroImaging GmbH, Jena, Germany).

\section{Cell counting}

T24 cells were seeded at 10,000 cells/well in a 24-well plate. After treatments, cells were trypsinized and incubated in a trypan blue solution $(0.4 \% w / v$ final dye concentration, SigmaAldrich). Non-stained viable cells were counted by using the Bürker chamber.

\section{MTT assay}

Cell viability after HNE treatments was determined through the 3-(4,5-dimethyl thiazol-2-yl)-2,5diphenyltetrazolium bromide (MTT) assay, as previously described [16]. Briefly, T24, CRL2335, 
and A375 cells were seeded at 1,000 cells/well in 96-well plates in 200 عl of serum-supplemented medium and treated as indicated in the ñResultsò section. Untreated cells were used as control. After this period, the drug was removed and the MTT assay was performed. MTT was added to control and treated cells to a final concentration of $0.5 \mathrm{mg} / \mathrm{ml}$ (Sigmaï Aldrich) for $2 \mathrm{~h}$. The medium was then removed, and the cells were lysed with 100 عl of DMSO. Absorbance was recorded at 530 $\mathrm{nm}$ by a 96-well-plate ELISA reader (iMark Microplate Reader, Bio-Rad Laboratories). This colorimetric assay may be interpreted as a measure of both cell viability and cell proliferation [37].

\section{Apoptosis}

T24 cells were seeded in 6-well plates (250,000 cells/well), treated and collected as indicated in the ñResultsò section. Adherent and nonadherent cells were harvested after cell treatments, washed in 1xPBS, and subsequently stained with FITC-Annexin 5 and PI according to the manufacturer protocol (FITC Annexin V Apoptosis Detection Kit, Cat. N ${ }^{\circ}$ 556547, BD Biosciences, Milan, Italy). Cells were analyzed by a FACScan cytometer (Becton Dickinson, Accuri).

\section{Cell cycle}

T24 cells were seeded in 6-well plates (250,000 cells/well), treated and collected as indicated in the ñResultsò section. Adherent and non-adherent treated and control cells were harvested after the cell treatments. Cells were washed with 1xPBS, fixed in $70 \%$ cold ethanol, resuspended in a buffer containing $0.02 \mathrm{mg} / \mathrm{ml}$ RNase A (Sigma-Aldrich), $0.05 \mathrm{mg} / \mathrm{ml}$ propidium iodide (PI) (Sigmaï Aldrich), $0.2 \%$ v/v Nonidet P-40 (Sigmaï Aldrich), 0.1\% w/v sodium citrate (Sigmaï Aldrich), and analyzed with a FACScan cytometer (Becton Dickinson, Accuri).

\section{Cell motility assay}

In the wound-healing assay, after starvation for $18 \mathrm{i} 24 \mathrm{~h}$ in serum-free medium, T24 cells were plated onto 6-well plates $\left(10^{6}\right.$ cells/well) and grown to confluence. Cell monolayers were wounded by scratching with a pipette tip along the diameter of the well, and they were washed twice with serum-free medium before the $10 \mu \mathrm{M} \mathrm{HNE}$ treatment. In order to monitor cell movement into the wounded area, five fields of each wound were photographed immediately after the scratch (T0) and after $24 \mathrm{~h} \mathrm{[38].} \mathrm{The} \mathrm{endpoint} \mathrm{of} \mathrm{the} \mathrm{assay} \mathrm{was} \mathrm{measured} \mathrm{by} \mathrm{calculating} \mathrm{the} \mathrm{reduction} \mathrm{in} \mathrm{the} \mathrm{width} \mathrm{of}$ the wound after $24 \mathrm{~h}$ and compared to $\mathrm{T} 0$ which is set at $100 \%$. The area of wound healing was calculated by using the ImageJ software [39].

\section{Cell invasion assay}


In the Transwell Boyden chamber (BD Biosciences, Milan, Italy) invasion assay, T24 cells $(8,000)$ were plated onto the apical side of Matrigel-coated $(50 \mu \mathrm{g} / \mathrm{ml})$ filters in serum-free medium with or without HNE $10 \mu \mathrm{M}$. Medium containing FCS 20\% was placed in the basolateral chamber as chemoattractants. The chamber was incubated at $37{ }^{\circ} \mathrm{C}$ under $5 \% \mathrm{CO}_{2}$. After $24 \mathrm{~h}$, the cells on the apical side were wiped off with Q-tips. The cells that migrated to the bottom of the filter were stained with crystal violet and counted (all fields of each quadruplicate filter) with an inverted microscope. Five different experiments were performed. The results are expressed as the number of invading cells per high-power field.

\section{Angiogenesis assay}

In the tube-formation assay, HUVEC cells were seeded onto 24 -well plates $\left(5 \times 10^{4}\right.$ cells/well) previously coated with 150 عl growth factorï reduced Matrigel (BD Biosciences) in the presence of conditioned media derived from T24 untreated or treated with HNE, as described in the ñResultsò section. The morphology of the capillary-like structures formed by the HUVECs was analyzed after $6 \mathrm{~h}$ of culture using an inverted microscope and was photographed with a digital camera. Tube formation was analyzed with an imaging system (Image-Pro).

Measurement of HNE disappearance from the medium of $T 24$ cell cultures.

T24 cells were seeded in 24-well plates (50,000 cells/well). They were untreated or incubated with $10 \mu \mathrm{M}$ HNE in RPMI medium with $10 \%$ FCS and maintained at $37{ }^{\circ} \mathrm{C}$ in a humidified atmosphere of $5 \% \mathrm{CO}_{2}$. After 0,30, $60 \mathrm{~min}, 3 \mathrm{~h}$, and $6 \mathrm{~h}$ aliquots of medium were added to an equal volume of $\mathrm{C}_{2} \mathrm{H}_{3} \mathrm{~N} / \mathrm{CH}_{3} \mathrm{COOH}$ 96:4 (v/v) and injected in the HPLC (L2 Binary Pump, Perkin Elmer instrument,), equipped with a UV-vis detector (Waters S.p.A., Vimodrone, Milan, Italy). HNE was then separated at the following conditions: RP-18 column (Merck, Darmstadt, Germany), $\mathrm{C}_{2} \mathrm{H}_{3} \mathrm{~N}$ /water $\left(\mathrm{H}_{2} \mathrm{O}\right) 42: 58(\mathrm{v} / \mathrm{v})$ as mobile phase, $1.0 \mathrm{ml} / \mathrm{min}$ flow rate, $223 \mathrm{~nm}$ optical density UV detector setting with 0.05 absorbance units for full recorder scale, 20 عM injected sample volume. Peak identification and quantification were based on reference chromatograms and a calibration curve obtained from standard $\mathrm{HNE}$ solutions (1 to $10 \mathrm{mM}$ ) in $\mathrm{H}_{2} \mathrm{O} / \mathrm{C}_{2} \mathrm{H}_{3} \mathrm{~N} / \mathrm{CH}_{3} \mathrm{COOH}$.

\section{Analysis of GSH contents}

The GSH contents were assessed by determining non-protein sulphydryl contents with the Ellmanôs method, as previously reported [40]. Briefly, T24 cells were seeded in Petri dishes $100 \mathrm{~mm}\left(2 \times 10^{6}\right.$ 
cells/dish) and treated as indicated in the r̃Resultsò section. After washing in cold $1 \times \mathrm{PBS}, 4 \times 10^{6}$ cells were collected by using a cell scaper and centrifuged $1,000 \mathrm{rpm}$ for $10 \mathrm{~min}$ at $4{ }^{\circ} \mathrm{C}$. Pellets were resuspended in 5\% Trichloroacetic acid (TCA) and $5 \mathrm{mM}$ EDTA. Insoluble proteins were then discarded by high-speed centrifugation at $4{ }^{\circ} \mathrm{C}$. The supernatants were collected and added to a 0.4 M Tris-EDTA buffer $\mathrm{pH} 8.9$ for GSH concentration measurement, while the pellets were resuspended in $50 \mu \mathrm{l} \mathrm{NaOH} 1 \mathrm{M}$ to measure the protein content, as above described. GSH concentration was determined after $2 \mathrm{~min}$ incubation with 5,5Alithiobis-2-nitrobenzoic acid (DTNB) by measuring the production of 5Alghio-2-nitrobenzoic acid (TNB) at $412 \mathrm{~nm}$ on a spectrophotometer. GSH standard curve was used to calculate the concentration of GSH in the samples. These results were expressed nmol GSH per mg of proteins.

\section{Quantitative reverse transcription polymerase chain reaction ( $q R T-P C R)$}

T24 cells were seeded in 6-well plates $(250,000$ cells/well), treated and collected as indicated in the ñResultsò section. Total RNA was isolated using the TRIZOL reagent according to the manufacturer's instructions (Invitrogen, Milan, Italy). For reverse transcription, $1 \varepsilon \mathrm{g}$ of cells total RNA, $25 \mu \mathrm{M}$ random hexamers and $100 \mathrm{U}$ of Reverse Transcriptase (Thermo Fisher Scientific, Milan, Italy) were used. Gene expression levels were measured by quantitative real-time PCR (qRT-PCR) in an iCycler (Bio-Rad Laboratories, Segrate-Milan, Italy). Abelson (Abl) gene was utilized as housekeeping control. The following TaqMan® Gene Expression Assay (Thermo Fisher Scientific) were used: Hs00371735_m1, Life Technologies for YAP gene and Hs00245445_m1 for Abl gene. For each PCR reaction, $50 \mathrm{ng}$ of cDNA was added to PCR reaction mix containing $1 \mathrm{x}$ TaqMan Universal PCR Master Mix (Thermo Fisher Scientific), 1x TaqMan® Gene Expression Assay (Thermo Fisher Scientific) and distilled water to a final volume of $10 \mathrm{ul}$. All analyses were carried out in duplicate; the results showing a discrepancy greater than one cycle threshold in one of the wells were excluded. The results were analyzed using the qopet method [41].

\section{Immunoprecipitation assay}

T24 cells were seeded in 6-well plates (250,000 cells/well), treated and collected as indicated in the ñResultsò section. For the IP assay, at least 500,000 cells were resuspended in a lysis buffer composed of with $20 \mathrm{mM}$ Trisï HCl, pH 7.4, $150 \mathrm{mM} \mathrm{NaCl}, 5 \mathrm{mM}$ EDTA, $1 \%$ v/v Triton X-100, PMSF 1 mM (P-7626, Sigma- Aldrich) + sodium orthovanadate 1 mM (S-6508, Sigma- Aldrich), the Complete ${ }^{\mathrm{TM}}$ Protease Inhibitor Cocktail (sc-29130, Santa Cruz) and incubated on ice for $10 \mathrm{~min}$; the lysates were then passed through a 25-gauge needle of a syringe. After centrifugation $(10,000 \mathrm{~g}$ 
for 10 min at $4{ }^{\circ} \mathrm{C}$ ), the supernatants were collected, and the protein concentration was determined by using a commercially available kit (Bio-Rad Laboratories). After that, $500 \mu \mathrm{g}$ of cell lysate was incubated with $1.2 \mu \mathrm{g}$ of YAP (sc15407) on a rocking shaker overnight at $4{ }^{\circ} \mathrm{C}$. The immunocomplexes were captured by adding $40 \mu \mathrm{g}$ Protein A Sepharose Beads (P-6649, SigmaAldrich) for $1 \mathrm{~h}$ at $4{ }^{\circ} \mathrm{C}$. The immunocomplex-sepharose beads were then collected with brief centrifugation at 14,000 rpm for $5 \mathrm{sec}$; the pellets were collected by centrifugation and supernatants were discarded. The pellets were washed extensively in the lysis buffer. For the last washing step, a solution containing lysis buffer plus $0.2 \mathrm{M}$ Tris/ $\mathrm{HCl}$ buffer, $\mathrm{pH} 6.8,2 \%$ SDS, $30 \%$ glycerol, and $16 \%$ 2-mercaptoethanol was used. The pellets were then boiled for $2 \mathrm{~min}$. The supernatants were collected and subjected to SDS/PAGE, followed by Western blot analysis for ubiquitin.

\section{Transient transfection}

For transient transfection experiments, T24 cells were seeded in 6-well plates (90,000 cells/well), and incubated $24 \mathrm{~h}$ before transfecting with pCMV6_YAP1 (1.5 $\mu \mathrm{g}$ of YAP1 cDNA), or pCAMV6empty Vectors (Origene, Rockville, MD, USA), both kindly provided by Prof. Rosa M. Pascale (University of Sassari, Italy) [42], by FuGene HD reagent (SwitchGear Genomics, USA), according to manufacturer's protocol. After $30 \mathrm{~h}$ from trasfection, the cells were treated with HNE $10 \mu \mathrm{M}$ and $20 \mu \mathrm{M}$ for $6 \mathrm{~h}$ and $24 \mathrm{~h}$. YAP expression was determined by WB, while PARP cleavage, also evaluated by WB, was analyzed as a measure of apoptosis. For MTT analysis, T24 cells were seeded in 96-well plates (1,000 cells/well), and incubated $24 \mathrm{~h}$ before transfecting with pCMV6_YAP1 $(0.1 \mu \mathrm{g}$ of YAP1 cDNA) or pCAMV6-empty Vectors. After $30 \mathrm{~h}$ form transfection, the cells were treated with HNE $10 \mu \mathrm{M}$ and $20 \mu \mathrm{M}$ and MTT analysis was performed as previously described at $24 \mathrm{~h}, 48 \mathrm{~h}$, and $72 \mathrm{~h}$.

\section{Statistical analysis}

Data were expressed as means \pm SD. Significance between experimental groups was determined by one-way ANOVA followed by the Bonferroni multiple comparison post-test using GraphPad InStat software (San Diego, CA, USA). Values of pÒ. 05 were considered statistically significant.

\section{Results}

HNE inhibited YAP expression and its target genes in T24 human bladder cancer cells 
To examine the effect of HNE on YAP expression in bladder cancer cells, at first we evaluated the basal protein expression of YAP in four different bladder cancer cell lines: T24, 253J, 253J B-V, and UM-UC-3. We found that T24 cells showed the highest level of this protein (Figure S1 A), so they were selected for the study. T24 cells were then treated with 10 and $20 \mu \mathrm{M}$ HNE and the YAP protein content was measured at $3 \mathrm{~h}, 6 \mathrm{~h}, 24 \mathrm{~h}$, and $48 \mathrm{~h}$ (Fig 1A). After $3 \mathrm{~h}$ we didnô find any modulations after treatments, while after $6 \mathrm{~h}$ we observed a strong down-regulation of this protein with both concentrations of HNE. At $24 \mathrm{~h}$ from the treatment, $20 \mu \mathrm{M}$ HNE still inhibited YAP expression significantly, but its expression was higher than that detected at $6 \mathrm{~h}$. After $24 \mathrm{~h}$ from 10 $\mu \mathrm{M}$ HNE treatment, the expression of YAP was similar to control values. After $48 \mathrm{~h}$ (Fig.1A) and $72 \mathrm{~h}$ (data not shown), both 10 and $20 \mu \mathrm{M}$ HNE did not modify YAP expression with respect to control. Moreover, we confirmed by IF analysis the down-regulation of YAP protein at $6 \mathrm{~h}$ after HNE treatments (Fig 1B). Finally, we demonstrated that the reduction of YAP protein, $6 \mathrm{~h}$ after HNE treatment, corresponded to the inhibition of YAP activity, by obtaining a down-regulation of target genes controlled by the complex YAP-TEAD, such as survivin and Cyr6 (Fig 1C). On the contrary, at $6 \mathrm{~h}$ the target gene MnSOD, controlled by the complex YAP-FoxO1, was not affected by HNE treatments.

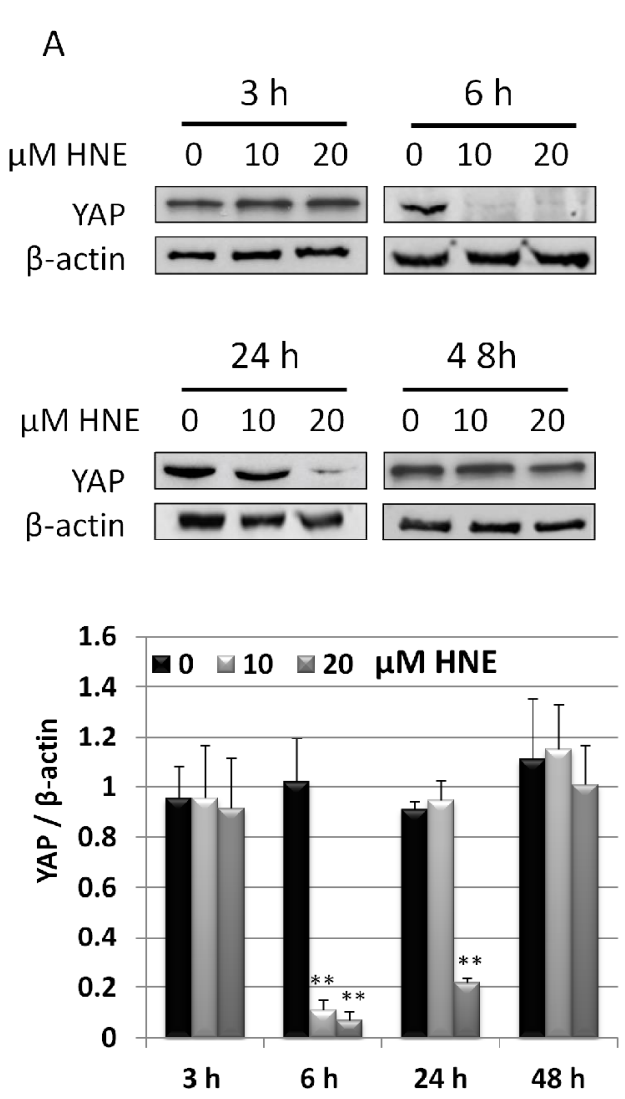

Fig 1
B
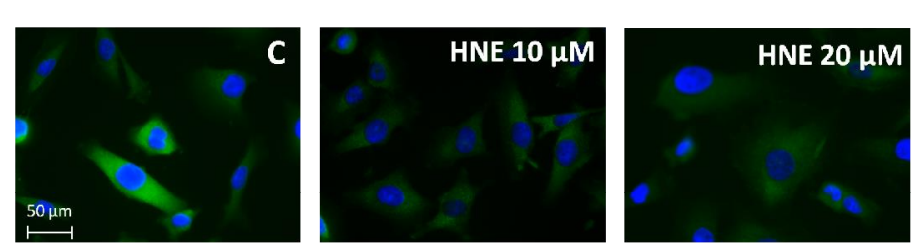

C
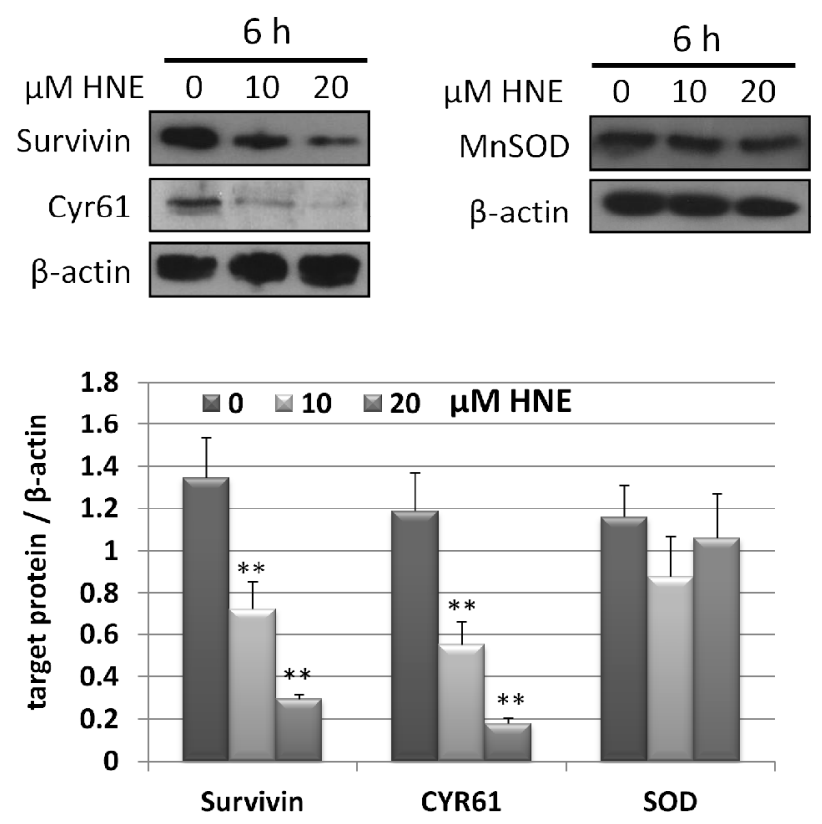
Fig 1: HNE inhibited YAP protein expression and its target genes in T24 cells. Panel A: WB analysis of YAP in T24 untreated (0) or treated cells with $10 \mu \mathrm{M}$ and $20 \mu \mathrm{M} \mathrm{HNE}$ at $3 \mathrm{~h}, 6 \mathrm{~h}, 24 \mathrm{~h}$, and $48 \mathrm{~h}$ from the treatment. Equal protein loading was confirmed by exposure of the membranes to the anti- $b$-actin antibody. Below quantification of protein products was performed by densitometric scanning. Data were normalized using the 6 -actin signal and are indicated as the mean \pm SD from three independent experiments. ** p-value Oे.01 vs. untreated control cells (0). Panel B: IF analysis of YAP protein expression in untreated T24 cells (control, C) or treated with for $6 \mathrm{~h} 10 \mu \mathrm{M}$ and $20 \mu \mathrm{M}$ HNE. YAP was detected by using an anti-YAP antibody and a FITC-conjugated secondary antibody (green). The mounting medium contained DAPI to highlight the cellular nucleus (blue). These are images of one representative experiment from a series of three with similar results (data not shown). Panel C: WB analysis of survivin, Cyr61, and MnSO, three target genes of YAP, in T24 cells untreated (0) or treated with $10 \mu \mathrm{M}$ and $20 \mu \mathrm{M}$ HNE, $6 \mathrm{~h}$ from the treatment. Equal protein loading was confirmed by exposure of the membranes to the anti-b-actin antibody. Below quantification of protein products was performed by densitometric scanning. Data were normalized using the 6 -actin signal and are indicated as the mean \pm SD from three independent experiments. $* *$ p-value Oे.01 vs. untreated control cells (C).

\section{$\underline{\text { HNE inhibited cell proliferation and induced cell death in T24 cells }}$}

Since YAP is a powerful regulator of cell proliferation and survival, we wanted to verify if the YAP inhibition in HNE-treated T24 cells was accompanied by an inhibition of these two parameters. Thus, T24 cells were treated with 20 and $10 \mu \mathrm{M} \mathrm{HNE}$, and the counting of cells, MTT values and Ki67 expression were evaluated. Results demonstrated that HNE induced a significant concentration-dependent inhibition of the number of cells counted by Bürker chamber (Fig 2A), as well as a reduction of the MTT values (Fig. 2B), at $24 \mathrm{~h}, 48 \mathrm{~h}$, and $72 \mathrm{~h}$ from the treatment. Moreover, we evaluated Ki67 expression, as an index of proliferation, $48 \mathrm{~h}$ after HNE treatments.

Results confirmed a reduction of Ki67 expressing cells after treatment with both HNE concentrations. 
A

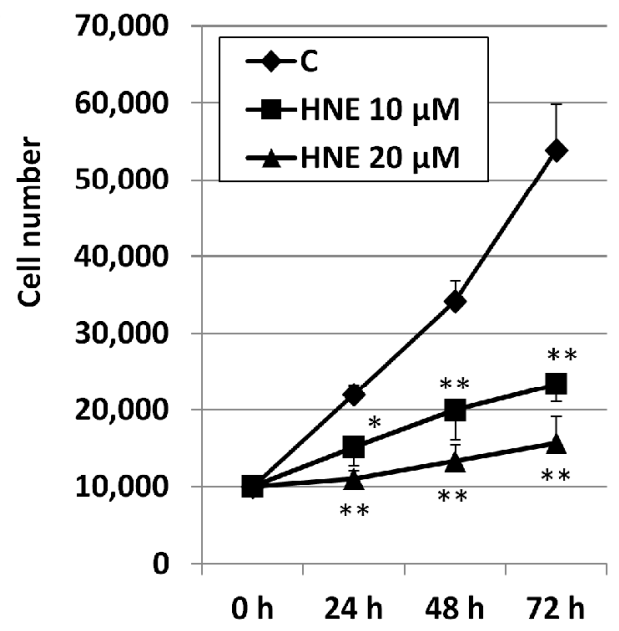

B

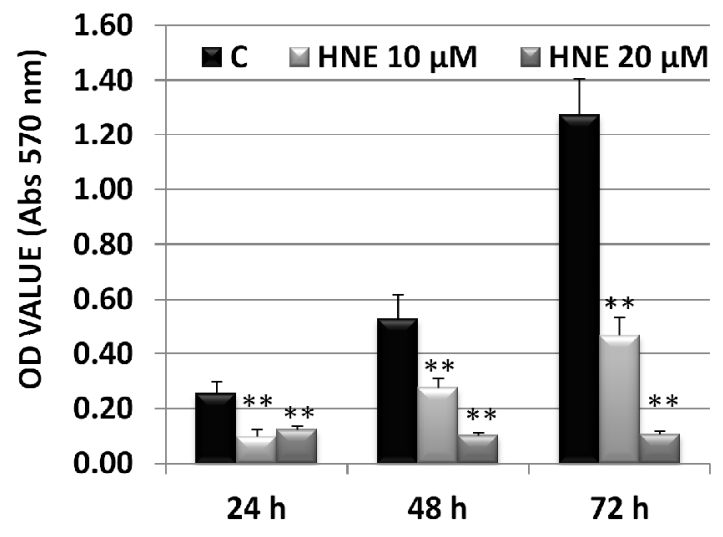

C

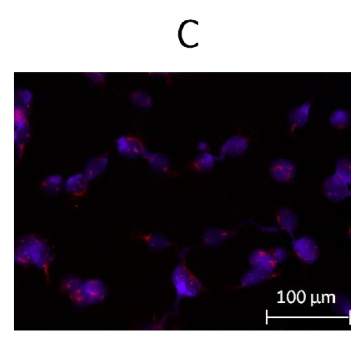

$100 \mu \mathrm{m}$
HNE $10 \mu \mathrm{M}$

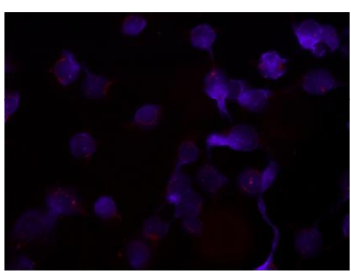

HNE $20 \mu \mathrm{M}$

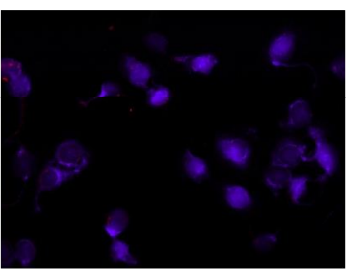

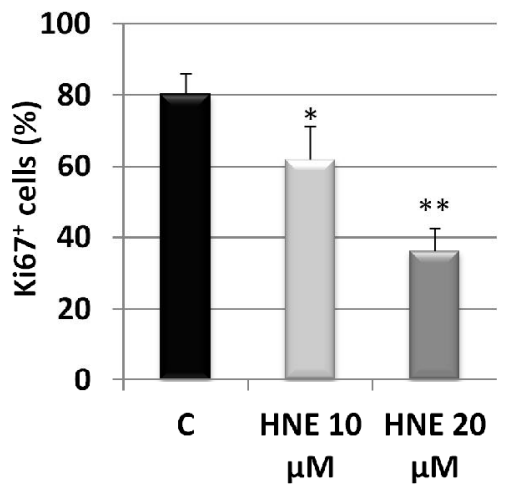

Fig 2

Fig 2. HNE inhibited cell proliferation in T24 cells. Panel A: T24 cell growth after treatments with $10 \mu \mathrm{M}$ and $20 \mu \mathrm{M}$ HNE, or untreated (control, C). Cells were seeded at 10,000 cells/well in 24-well plates, and the cell number was evaluated at $24 \mathrm{~h}, 48 \mathrm{~h}$, and $72 \mathrm{~h}$ by counting in a Bürker chamber. Data are the means \pm SD of three separate experiments, each performed in triplicate. *pÖ.05vs C. **pÒ.01vs C. Panel B: MTT assay of T24 untreated (Control, C) or treated cells with $20 \mu \mathrm{M}$ and $10 \mu \mathrm{M} \mathrm{HNE}$ at $24 \mathrm{~h}, 48 \mathrm{~h}$, and $72 \mathrm{~h}$. Results are the mean \pm SD of three separate experiments, each performed in sextuplicate. **pơ.01vs C. Panel C: IF analysis of Ki67 protein expression in untreated T24 cells (control, C) or treated with $10 \mu \mathrm{M}$ and $20 \mu \mathrm{M}$ HNE at $48 \mathrm{~h}$ from the treatment. Ki67 was detected by using an anti- Ki67 antibody and a Cys-3 secondary antibody (red). The mounting medium contained Hoechst 33342 to highlight the cellular nucleus (blue). These are images of one representative experiment from a series of three experiments with similar results. On the right, the quantification of Ki67 positive cells is shown, expressed as percentage of total cells. Three samples were analyzed in each condition and at least 100 cells were counted in each sample. Results are the mean \pm SD. *pÖ.05vs C. **pOे.01vs C.

The MTT assay, by assessing the metabolic activity, can be a measure of both cell viability and cell proliferation [37]; thus, to measure the contribution of cell death to the above-observed inhibition of MTT value, Annexin-V/IP assay was performed in T24 cells untreated or treated with 10 and 20 $\mu \mathrm{M}$ HNE at $15 \mathrm{~h}$ and $24 \mathrm{~h}$ from the treatment (Fig. 3A). This assay can discriminate early apoptosis 
(annexin V-positive and PI-negative cells), late apoptosis (annexin V-positive and PI-positive cells), and necrotic (annexin V-negative and PI-positive) cell populations. At $15 \mathrm{~h}$ from the treatment, we did not observe any significant increase. Conversely, $24 \mathrm{~h}$ from the treatment with $20 \mu \mathrm{M}$ HNE, but not with $10 \mu \mathrm{M}$ HNE, a modest but significant increase of early and late apoptotic cells (13.85 \pm $1.23 \%$ and $6.91 \pm 0.99 \%$, respectively) (Fig 3A) was observed. To confirm the ability of $20 \mu \mathrm{M}$ HNE in inducing apoptosis, we evaluated the cleaved PARP expression, a well-known apoptosis marker. According to the results obtained with the Annexin-V/IP assay, the cleaved form of PARP was present in T24 cells $24 \mathrm{~h}$ after the treatment with the highest dose of HNE $(20 \mu \mathrm{M})$, but not with $10 \mu \mathrm{M}$ HNE.

A

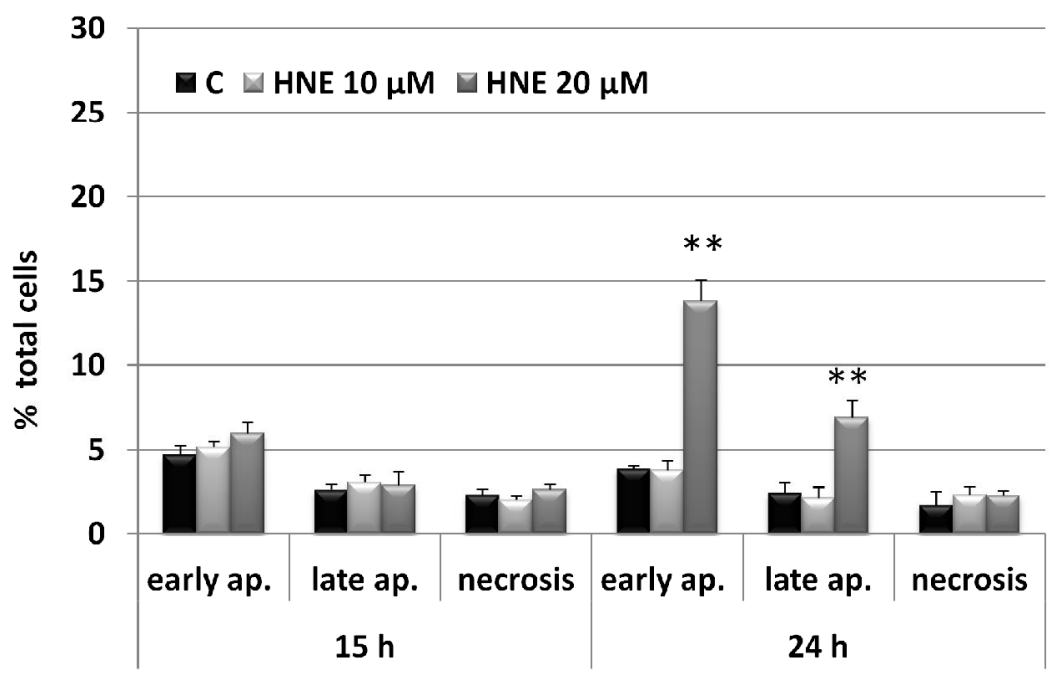

B
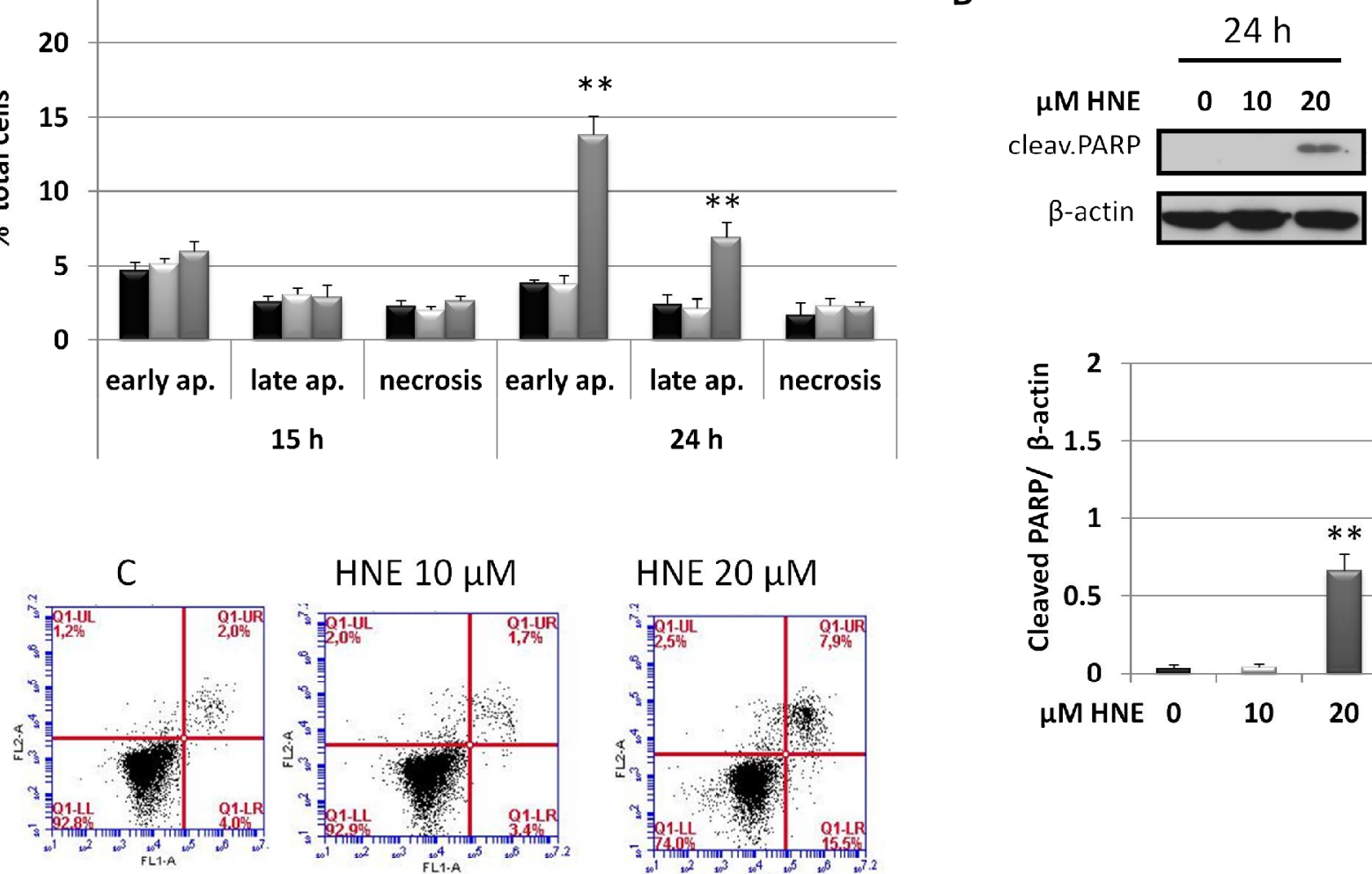

HNE $10 \mu \mathrm{M}$

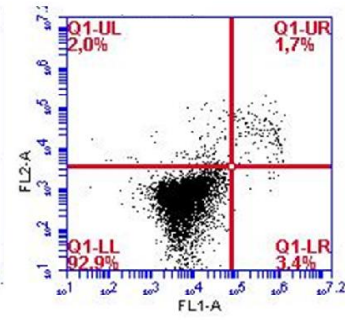

HNE $20 \mu \mathrm{M}$

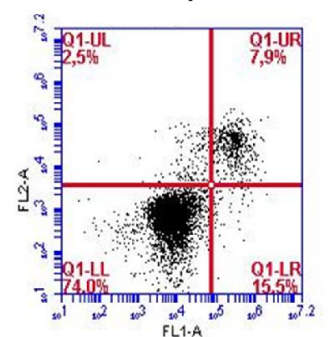

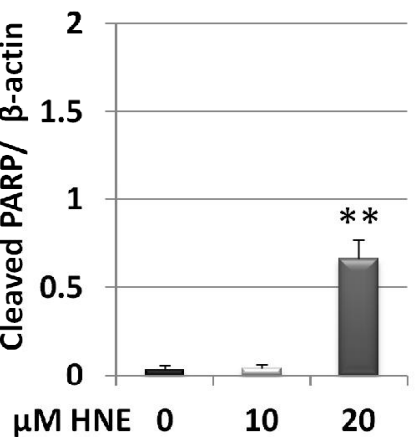

Fig 3

Fig. 3 HNE induced apoptosis in T24 cells. Panel A: Cytofluorimetric analysis of annexin V/PI staining in T24 cells untreated (Control, C), or treated with $10 \mu \mathrm{M}$ and $20 \mu \mathrm{M}$ HNE at the indicated time. Results show early apoptosis (annexin V-positive and PI-negative cells), late apoptosis (annexin V-positive and PI-positive cells), and necrotic (annexin V-negative and PI-positive) cell population Results were expressed as means \pm $\mathrm{SD}$ of three independent experiments, each performed in duplicate. **pOO.01 vs. C. Below the flow 
cytometry profiles of a representative experiment in Annexin V/IP stained T24 cells at $24 \mathrm{~h}$ are shown. The quadrants Q were defined as Q1-LL=live (Annexin V- and PI-negative), Q1-LR=early stage of apoptosis (Annexin V-positive/PI-negative), Q1-UR= late stage of apoptosis (Annexin V- and PI-positive) and Q1$\mathrm{UL}=$ necrosis (Annexin V-negative/PI-positive). Panel B: WB analysis of the apoptosis marker, the cleaved PARP, in T24 untreated (0) or treated cells with $10 \mu \mathrm{M}$ and $20 \mu \mathrm{M} \mathrm{HNE}$ at $24 \mathrm{~h}$ from the treatment. Equal protein loading was confirmed by exposure of membranes to the anti-b-actin antibody. Below, quantification of protein products was performed by densitometric scanning. Data were normalized using the 6 -actin signal and are indicated as the mean \pm SD from three independent experiments. ** p-value 0.01 vs. untreated control cells (C).

\section{HNE induced an increase of T24 cells in the G2/M phase}

To further study the antiproliferative activity of HNE we performed an analysis of the cell cycle in T24 cells at $24 \mathrm{~h}$ (Fig 4). The flow cytometry profiles of a representative experiment, with the relative percentages found, are shown in panel A. At $24 \mathrm{~h}$ from the treatment, both 10 and $20 \mu \mathrm{M}$ $\mathrm{HNE}$ induced a significant increase in the proportion of G2/M cells. $10 \mu \mathrm{M}$ HNE induced a higher increase $(28.31 \%)$ of $\mathrm{G} 2 / \mathrm{M}$ cells with respect to that obtained after $20 \mu \mathrm{M} \mathrm{HNE}$ treatment (20.35\%). In Fig. 4B the cell cycle distribution analysis of three independent experiments is shown. 

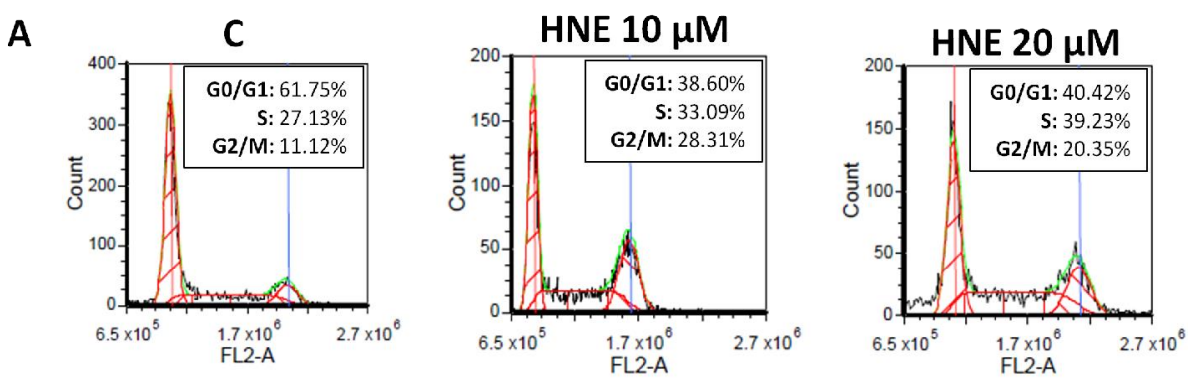

B

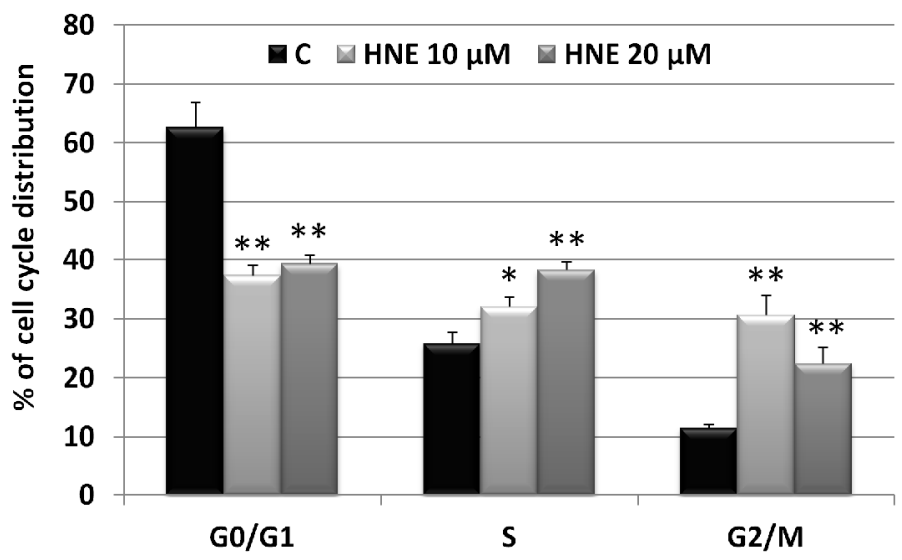

Fig 4

Fig. 4 HNE treatments induced G2/M cell accumulation. Panel A: Cell-cycle analysis of T24 untreated (Control, C) or treated with $10 \mu \mathrm{M}$ and $20 \mu \mathrm{M} \mathrm{HNE}$ at $24 \mathrm{~h}$ from the treatment. The data were captured by using a BD Accuri Flow cytometer and analyzed by using FCS Express Plus. Representative images and relative percentages are shown. Panel B: Percent of cell cycle distribution in T24 untreated (Control, C) or treated with $10 \mu \mathrm{M}$ and $20 \mu \mathrm{M}$ HNE at $24 \mathrm{~h}$ from the treatment. Data are the mean \pm SD of 3 separate experiments, each performed in duplicate. *pOे.05 vs. C, **pÖ.01 vs. C.

\section{$\underline{\text { HNE inhibited cell migration, invasion, and angiogenesis in T24 cells }}$}

As mentioned in the introduction, YAP regulates genes and signalling pathways that are critical for tumor cell migration and angiogenesis, both essential components of the metastatic cascade. Thus, we decided to investigate these two parameters after treatment with the lowest and non-toxic concentration of HNE (10 $\mu \mathrm{M})$ on T24 cells (Fig 5). Random cell migration in untreated or $10 \mu \mathrm{M}$ HNE- treated cells was measured after $24 \mathrm{~h}$ from the treatment (Fig 5A); we observed that HNEtreated cells were able to migrate into the scratch slower than untreated control cells (cell migration was reduced by around $50 \%$ with respect to the control). To further investigate the function of HNE in the invasion of T24 cells, the Transwell Boyden Chamber assay in matrigel was performed. The results revealed that the invasion was remarkably inhibited in $10 \mu \mathrm{M}$ HNE-treated T24 cells (Fig. $5 B)$. 
A
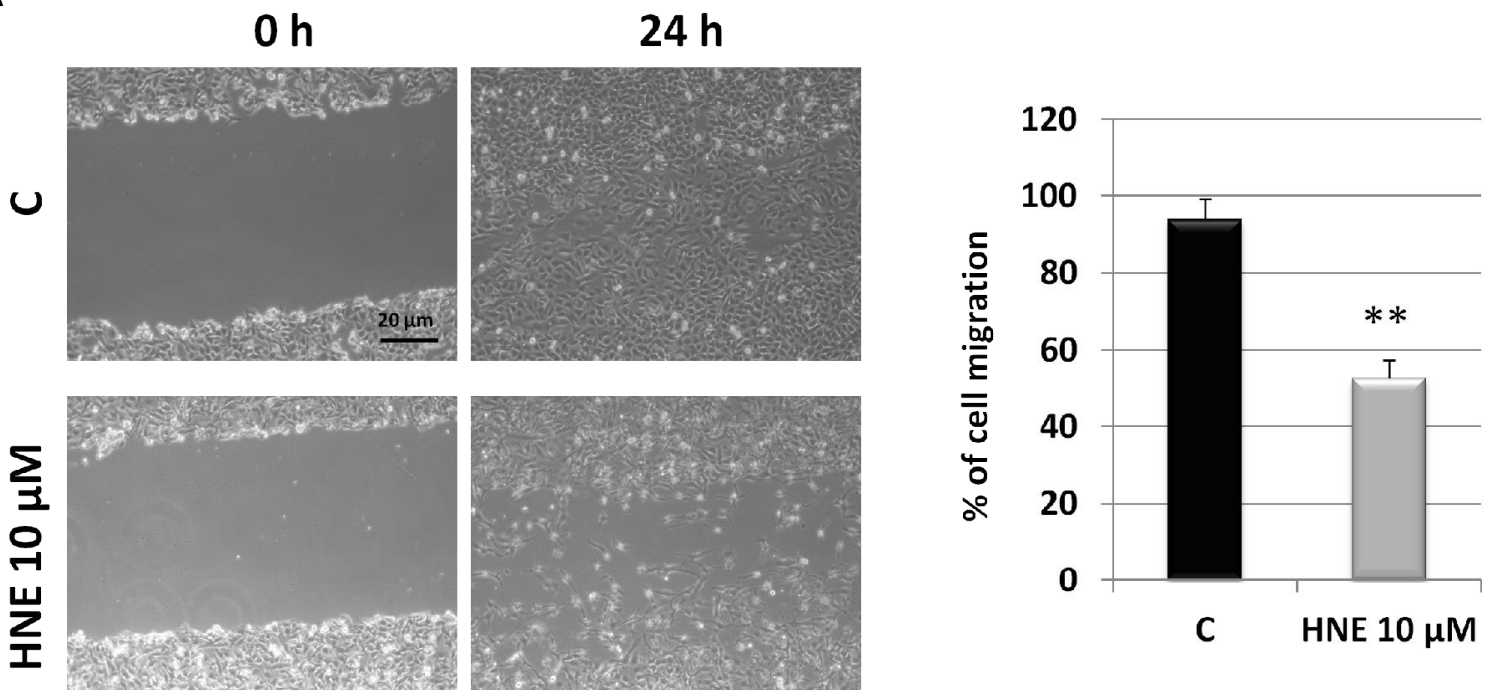

Fig 5

B

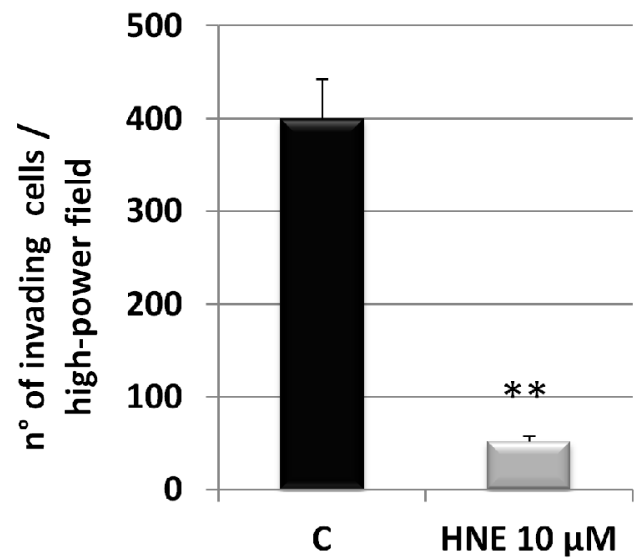

Fig. 5 HNE treatments inhibit cell migration. Panel A: wound healing assay at 0 (T0) and at $24 \mathrm{~h}$ in T24 cells untreated (C) or treated with $10 \mu \mathrm{M}$ HNE. On the right, the quantification of wound healing is shown. The endpoint of the assay was measured by calculating the reduction in the width of the wound after $24 \mathrm{~h}$ and compared to T0 which is set at $100 \%$. The data are the mean \pm SD of three independent experiments. ${ }^{* *}$ p-valueŌ.01 vs. C. Panel B: Boyden chamber assay at $18 \mathrm{~h}$ in T24 cells untreated (C) or treated with $10 \mu \mathrm{M}$ HNE. The results are expressed as the number of invading cells per high-power field, as the mean \pm SD of five independent experiments. ${ }^{* *}$ p-valueŌ. 01 vs.C.

For the angiogenesis assay, T24 cells were treated with $10 \mu \mathrm{M}$ HNE or untreated (control). After 6 $\mathrm{h}$, the conditioned cell culture media were collected and we assess their ability to affect the tubuleformation of HUVEC. The morphology of capillary-like structures formed by HUVEC was analyzed after $6 \mathrm{~h}$ of culture (Fig 6A). With $10 \mu \mathrm{M} \mathrm{HNE}$, the structure and the organization of the tubules were significantly lower $(19.5 \pm 5.2$ and $8.5 \pm 3.5$ number of tubes per field in untreated and $10 \mu \mathrm{M}$ HNE treated T24 cells, respectively). 
In order to check if in the conditioned medium was still present $10 \mu \mathrm{M} H \mathrm{HE}$, HNE disappearance was measured in the culture medium of T24 cells at $0 \mathrm{~min}, 30 \mathrm{~min}, 60 \mathrm{~min}, 3 \mathrm{~h}$, and $6 \mathrm{~h}$ from the treatment. As shown in Fig. 6B, $10 \mu \mathrm{M}$ HNE disappeared from the medium within $1 \mathrm{~h}$, and it is not any more detectable after $3 \mathrm{~h}$ and $6 \mathrm{~h}$ (data not shown). To state whether VEGF, one of the most important regulatory factors of angiogenesis, was involved in the HNE anti-angiogenic effect, we also evaluated its protein expression in HNE-treated T24 cells. As shown in Fig. 6C, both 10 and 20 $\mu \mathrm{M}$ HNE concentrations were able to significantly down-regulate VEGF expression.

A

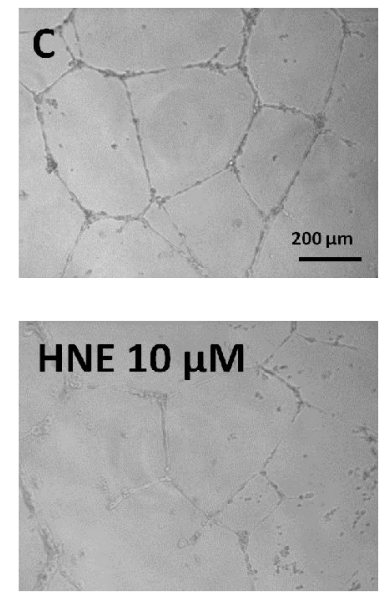

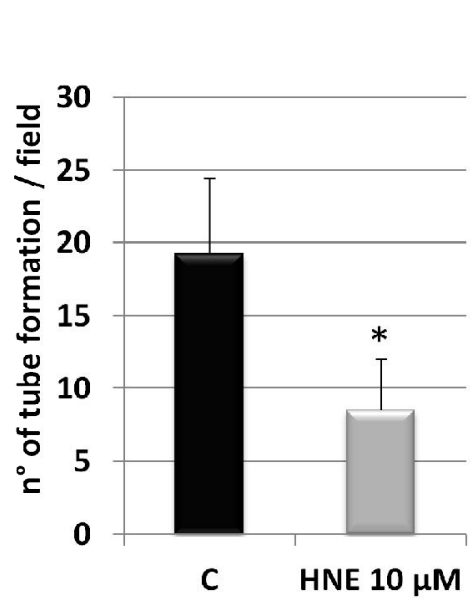

B

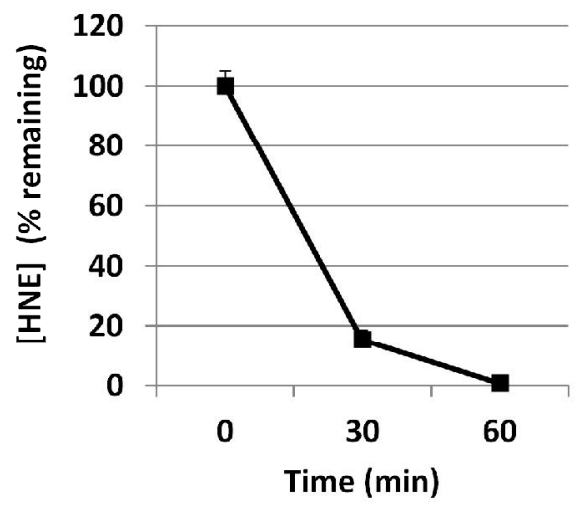

C
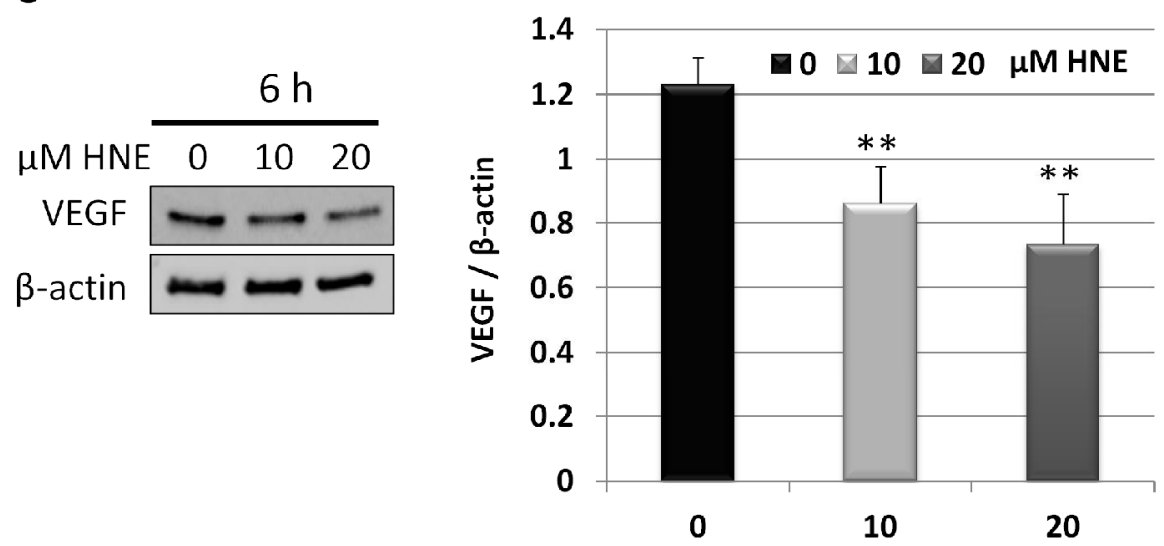

Fig 6

Fig. 6. Panel A: Tube formation assay on HUVEC after exposure to the conditioned media from untreated (C) or previously $10 \mu \mathrm{M}$ HNE-treated for $6 \mathrm{~h}$. Tube formation was then photographed after $6 \mathrm{~h}$ incubation with these conditioned media and evaluated by counting the total number of tubes in three wells; three different experiments were performed. The results are shown in the histogram below. The data are the mean \pm SD of three independent experiments. ${ }^{*}$ p-valueŌ. 05 vs. C. Panel B: HNE disappearance in T24 cell suspension. $10 \varepsilon \mathrm{EM} \mathrm{HNE}$ was added to the cell culture. After 0, 30, $60 \mathrm{~min}$, aliquots of medium were analyzed by HPLC. Results are expressed as percentage of T0 values $(9 \pm 1.3 \mu \mathrm{M})$. The data are the mean \pm SD of three independent experiments. Panel C: WB analysis of VEGF in T24 untreated (0) or treated cells with 10 and $20 \mu \mathrm{M} \mathrm{HNE}$ at $6 \mathrm{~h}$ from the treatment. Equal protein loading was confirmed by exposure of the 
membranes to the anti- 6 -actin antibody. On the right quantification of protein products was performed by densitometric scanning. Data were normalized using the b-actin signal and are indicated as the mean \pm SD from three independent experiments. ${ }^{* *}$ p-value Oे.01 vs. untreated control cells (C).

\section{HNE inhibited YAP expression and the MTT values in CRL2335 breast and A375 melanoma} cancer cells.

To determine whether the effect of HNE in inhibiting YAP expression was specific for T24 bladder cancer cells or a more common effect on tumor cells, YAP expression was analyzed after HNE treatments also in CRL2335 breast and A375 melanoma cancer cells, characterized by high levels of YAP protein content (Fig. S1 B). As performed in T24 cells, both cell lines were treated with 10 and $20 \mu \mathrm{M} \mathrm{HNE}$ and the YAP protein content was measured at $6 \mathrm{~h}$ after the treatment (Fig 7A). We observed a significant down-regulation of this protein with both concentrations of HNE in A375 cells, and a significant inhibition only with the highest HNE concentration in CRL2335 cells.

Moreover, in the same experimental conditions, we observed a significant concentration-dependent inhibition of the MTT values by HNE (Fig. 7B) in the A375 cell line, at all the times tested (24 h, $48 \mathrm{~h}, 72 \mathrm{~h}$ ), while a significant inhibition was observed only with the highest HNE concentration in CRL2335 cells $72 \mathrm{~h}$ after the treatment. 
A

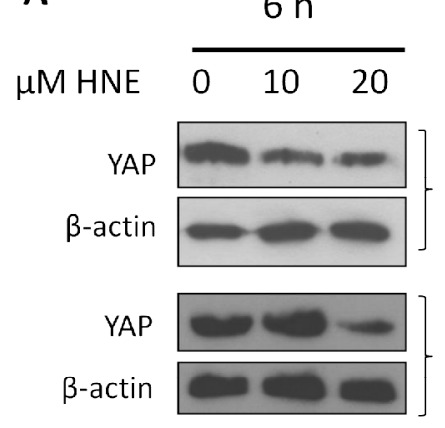

B

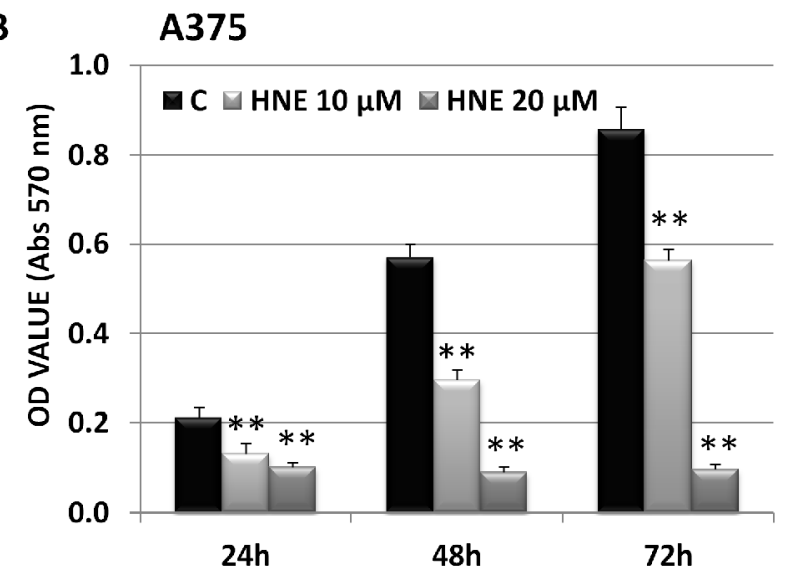

A375

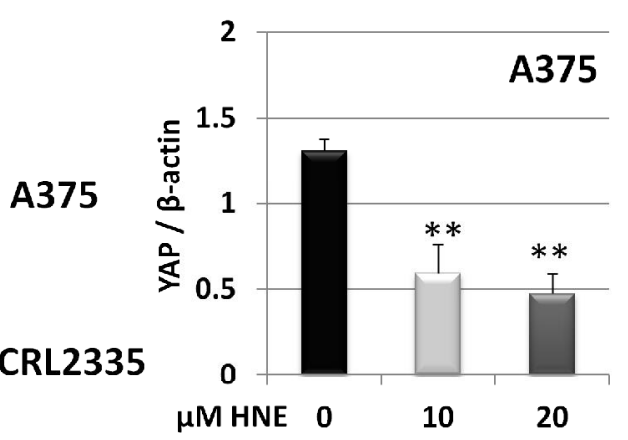

CRL2335 MM HNE 0

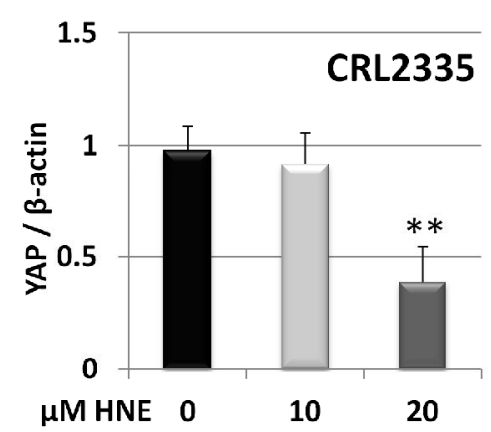

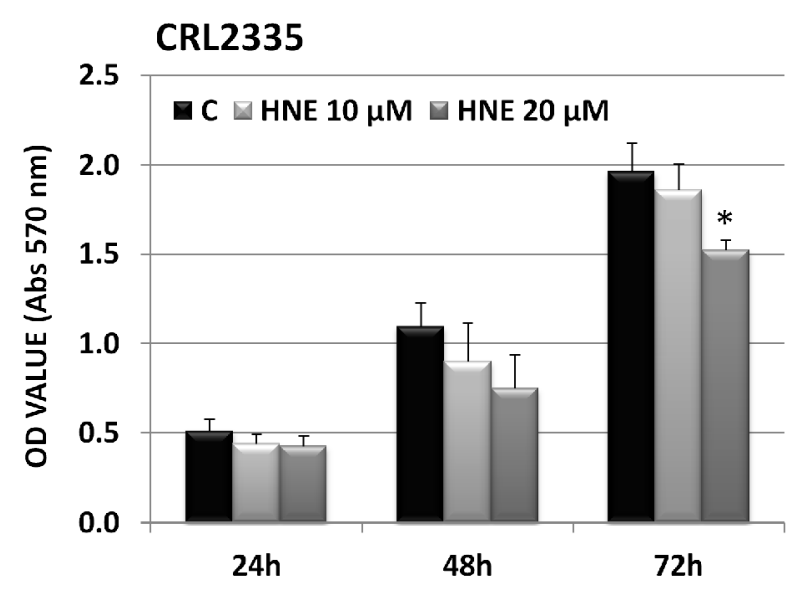

Fig 7

Fig 7. HNE inhibited YAP protein expression in melanoma A375 and CRL2335 breast cancer cells, and reduced the MTT values. Panel A: WB analysis of YAP in A375 and CRL2335 untreated (0) or treated cells with $10 \mu \mathrm{M}$ and $20 \mu \mathrm{M} \mathrm{HNE}, 6 \mathrm{~h}$ after the treatment. Equal protein loading was confirmed by exposure of the membranes to the anti- $\mathrm{b}$-actin antibody. On the right quantification of protein products was performed by densitometric scanning. Data were normalized using the 6 -actin signal and are indicated as the mean \pm SD from three independent experiments. ** p-value Oे.01 vs. untreated control cells (C).Panel B: MTT assay of A374 and CRL2335 untreated (Control, C) or treated cells with $10 \mu \mathrm{M}$ and $20 \mu \mathrm{M} \mathrm{HNE}$ at $24 \mathrm{~h}, 48 \mathrm{~h}$, and 72 h. Results are the mean \pm SD of three separate experiments, each performed in sextuplicate. *pŌ.05 vs. C, **pOे.01 vs. C.

\section{$\underline{\text { Redox regulation of YAP in } \mathrm{T} 24 \text { cells }}$}

To further study the mechanism of action of HNE on YAP protein inhibition, we evaluated whether this effect could be ascribed to the ability of aldehyde in perturbing the cellular redox state. As a first step, we verified if YAP could be regulated by altering the oxidative status of T24 cells. T24 cells were treated with the GSH-depleting agent DEM $(0.5 \mathrm{mM})$, with or without $2 \mathrm{~h}$ pre-incubation with the antioxidant NAC $(5 \mathrm{mM})$, a precursor of $\mathrm{GSH}$. According to literature data and our previous results [15-16], after $24 \mathrm{~h}$ we confirmed that DEM treatment caused a substantial decrease 
in the GSH level, while the NAC significantly increased it; moreover, the pre-treatment with NAC completely prevented the inhibition exerted by DEM (Fig 8A). In these experimental conditions, we analyzed YAP protein expression by $\mathrm{WB}$ and IF (Fig. 8B and C), with overlapping results: a significant down-regulation of YAP protein content in DEM-treated cells was observed; conversely, NAC treatment alone didnô affect YAP expression, while pre-treatment with NAC abolished YAP inhibition caused by DEM. Therefore, these results confirmed that the expression of YAP may also be subjected to the control of the cellular redox state in the T24 bladder cancer cell line.

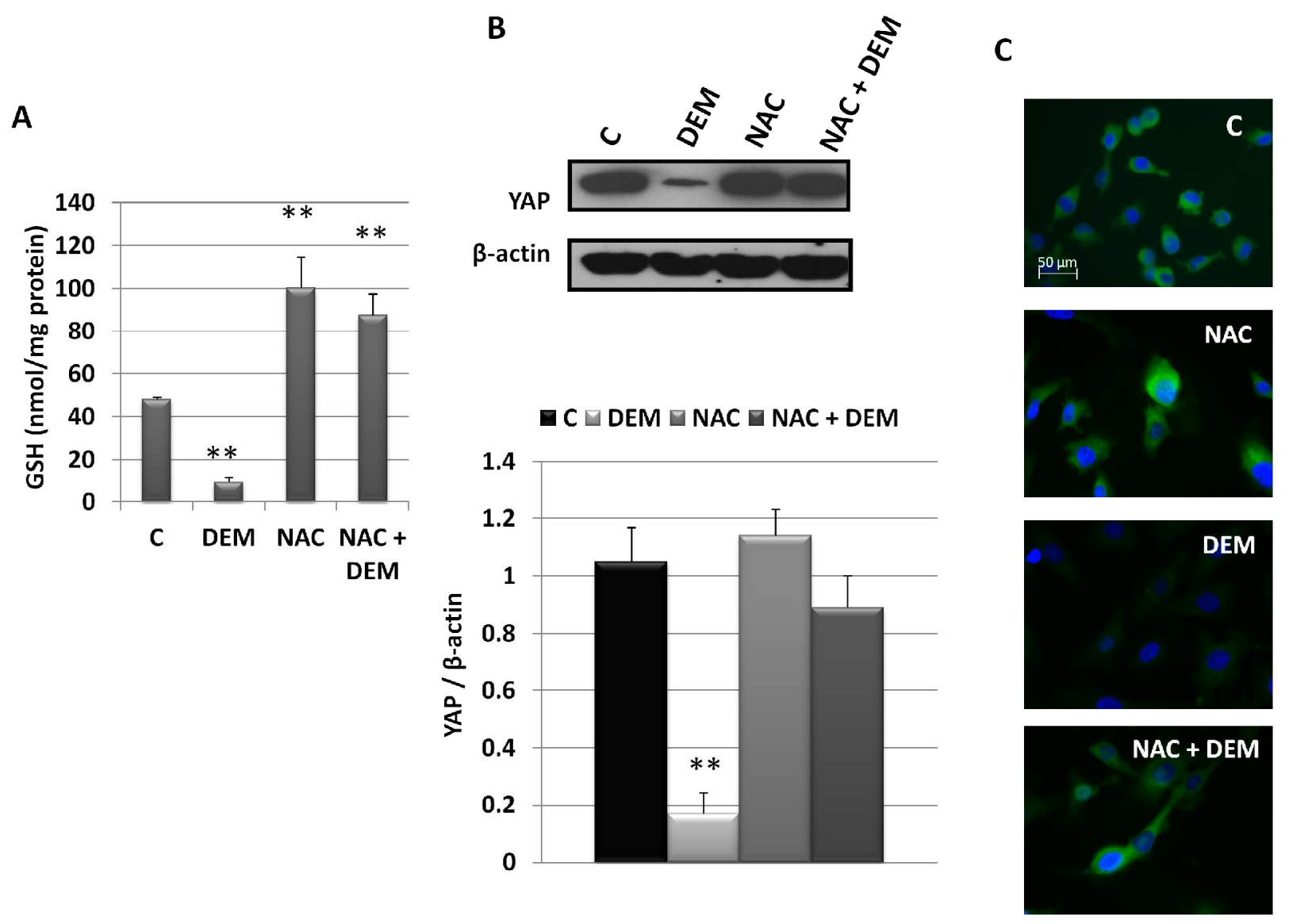

Fig 8

Fig 8. DEM inhibited YAP protein expression in T24 cells and the pre-treatment of NAC prevented this inhibition. Panel A: GSH level was evaluated in T24 untreated (control, C) or treated cells with $0.5 \mathrm{mM}$ DEM, $5 \mathrm{mM} \mathrm{NAC}$ or $5 \mathrm{mM} \mathrm{NAC} \mathrm{(2} \mathrm{h} \mathrm{pretreatment)}+0.5 \mathrm{mM}$ DEM (NAC+DEM) at $24 \mathrm{~h}$ from the treatment. Values are the mean \pm SD of 3 separate evaluations; ** p-value Oे.01 vs. C. Panel B: WB analysis of YAP in untreated or treated T24 cells as described in panel A. Equal protein loading was confirmed by exposure of the membranes to the anti- 6 -actin antibody. Below quantification of protein products was performed by densitometric scanning. Data were normalized using the 6-actin signal and are indicated as the mean \pm SD from three independent experiments. ** p-value 0.01 vs. untreated control cells (C). Panel C: IF analysis of YAP protein expression in untreated or treated T24 cells, as described in panel 
A. YAP was detected by using an anti-YAP antibody and a FITC-conjugated secondary antibody (green). The mounting medium contained DAPI to highlight the cellular nucleus (blue). These are images of one representative experiment from a series of three with similar results (data not shown).

HNE, as DEM, is a pro-oxidant agent, able to deplete GSH in several cells and tissues [21-23]. Thus, we evaluated if the HNE-induced YAP inhibition could be redox-dependent and if this phenomenon could be parallel to a reduction in the GSH content. T24 cells were treated with $10 \mu \mathrm{M}$ and $20 \mu \mathrm{M}$ HNE, with or without $2 \mathrm{~h}$ pre-incubation with $5 \mathrm{mM}$ NAC. The GSH level was determined after $2 \mathrm{~h}$ and $24 \mathrm{~h}$ (Fig 9A) from the treatment. We demonstrated that $20 \mu \mathrm{M}$, HNE caused a significant reduction of GSH level after $2 \mathrm{~h}$, while this inhibition disappeared after $24 \mathrm{~h}$. As previously reported, NAC significantly increased the GSH content, while the pre-treatment with NAC completely prevented the reduction elicited by HNE.

In Fig 9B and $\mathrm{C}$ the YAP protein expressions detected by WB and IF after $6 \mathrm{~h}$ from the treatment with $20 \mu \mathrm{M}$ HNE, with or without $2 \mathrm{~h}$ pre-incubation with $5 \mathrm{mM} \mathrm{NAC}$, are reported. In these experimental conditions we obtained similar results with both methods. In particular, we observed a significant down-regulation of YAP protein content in HNE-treated cells; NAC treatment alone didnâ affect YAP expression, while pre-treatment with NAC abolished the inhibition of YAP expression caused by the aldehyde. Moreover, in the same experimental conditions, survivin, and Cyr6, two YAP target genes, were also regulated with redox-dependent mechanisms, both paralleling to YAP protein level (Fig 9C). 

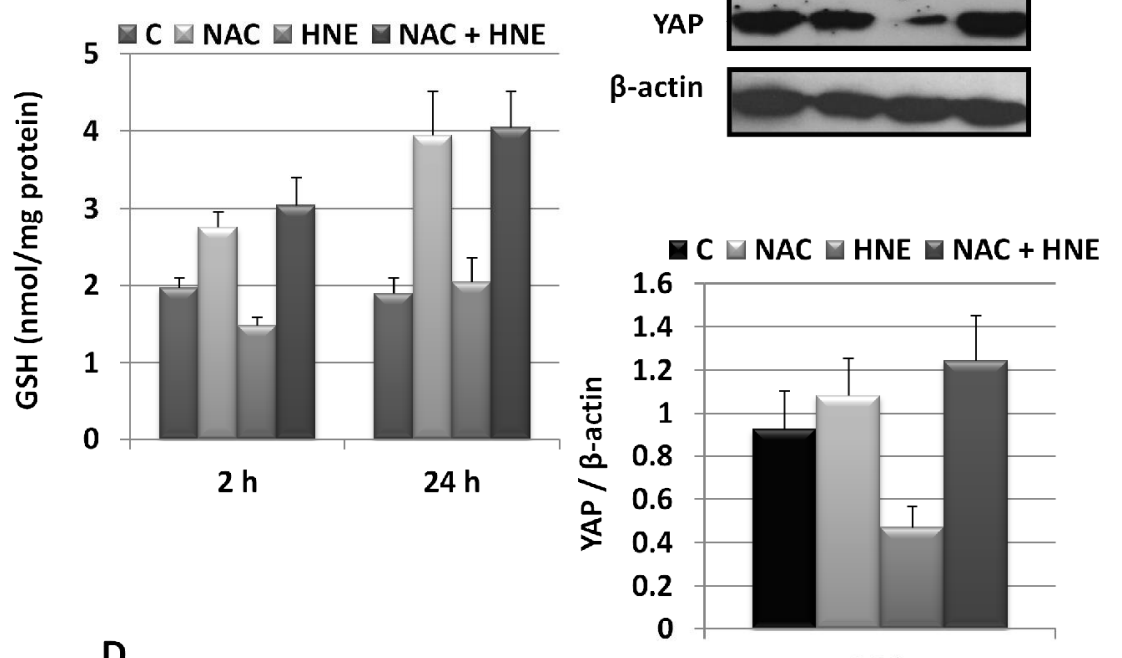

D

$24 \mathrm{~h}$

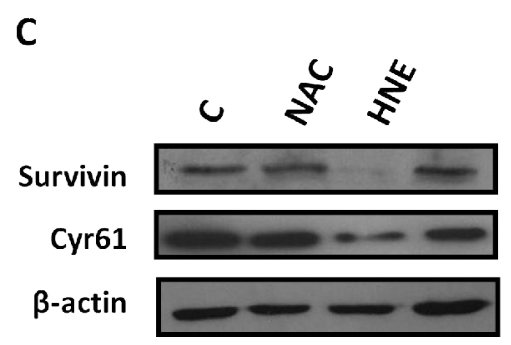

$C \square \mathrm{NAC} \square \mathrm{HNE} \square \mathrm{NAC}+\mathrm{HNE}$
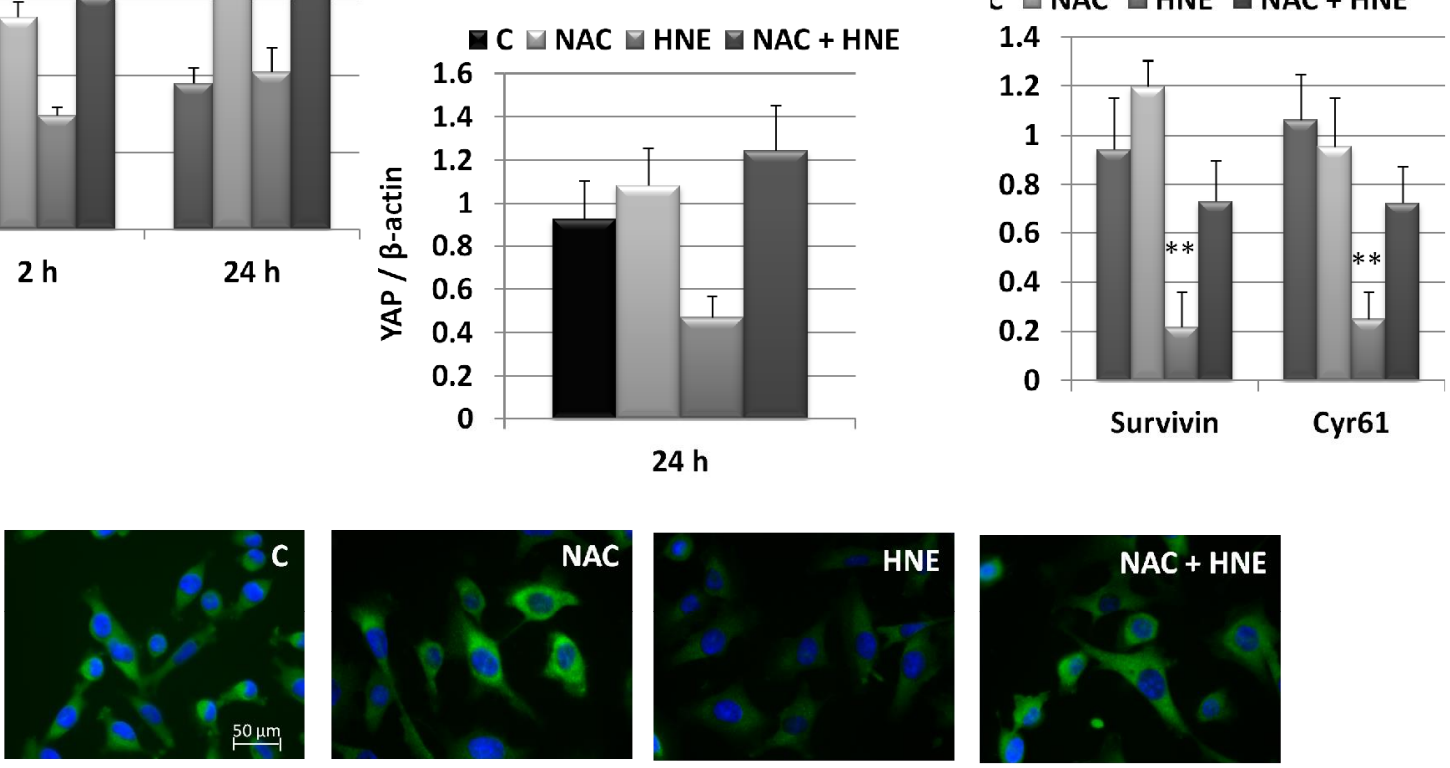

Fig 9

Fig 9. HNE inhibited YAP protein expression in T24 cells and the pre-treatment of NAC prevented this inhibition. Panel A: GSH level was evaluated in T24 untreated (control, C) or treated cells with 5 mM NAC, $20 \mu \mathrm{M} \mathrm{HNE}$, or $5 \mathrm{mM}$ NAC ( $2 \mathrm{~h}$ pre-treatment $)+20 \mu \mathrm{M}$ HNE(NAC+HNE) at $2 \mathrm{~h}$ and $24 \mathrm{~h}$ from the treatment. Values are the mean \pm SD of three separate evaluations; ** p-value Oे.01 vs. C. Panel B: WB analysis of YAP in untreated or treated T24 cells as described in panel A at $6 \mathrm{~h}$ from the treatment. Equal protein loading was confirmed by exposure of the membranes to the anti-b-actin antibody. Below quantification of protein products was performed by densitometric scanning. Data were normalized using the b-actin signal and are indicated as the mean \pm SD from three independent experiments. ** p-value Oे.01 vs. C. Panel C:WB analysis of YAP target genes, survivin and Cyr61, in untreated or treated T24 cells, as described in panel A. Equal protein loading was confirmed by exposure of the membranes to the anti- 6 -actin antibody. Below quantification of protein products was performed by densitometric scanning. Data were normalized using the 6 -actin signal and are indicated as the mean \pm SD from three independent experiments. ** p-value Oे.01 vs. C. Panel D: IF analysis of YAP protein expression in untreated or treated T24 cells as described in panel A. YAP was detected by using an anti-YAP antibody and a FITC-conjugated secondary antibody (green). The mounting medium contained DAPI to highlight the cellular nucleus (blue). These are images of one representative experiment from a series of three with similar results (data not shown). 
Pre-treatment with NAC not only prevented the HNE-induced down-regulation of YAP, but also all the biological effects elicited by HNE in T24 cells.

We investigated if NAC pretreatment could abolish the biological effects caused by the aldehyde on cell proliferation, apoptosis, cell cycle distribution, migration, and angiogenesis.

As reported in Fig 10A, we demonstrated that NAC was able to prevent the inhibition of cell proliferation induced by 10 and $20 \mu \mathrm{M} \mathrm{HNE}$ at all the time tested ( $24 \mathrm{~h}, 48 \mathrm{~h}, 72 \mathrm{~h}$ ), the induction of apoptosis by $20 \mu \mathrm{M}$ HNE (Fig. 10B), as well as the increase of the G2/M by 10 and $20 \mu \mathrm{M} \mathrm{HNE}$ at $24 \mathrm{~h}$ from the treatment (Fig. 10C). Consistent with these results, pre-treatment with NAC also abolished the inhibition of cell migrationat detected at $24 \mathrm{~h}$ from the treatment (Fig 11A) and angiogenesis, evaluated $6 \mathrm{~h}$ after the treatment with $10 \mu \mathrm{M}$ HNE (Fig. 11B).

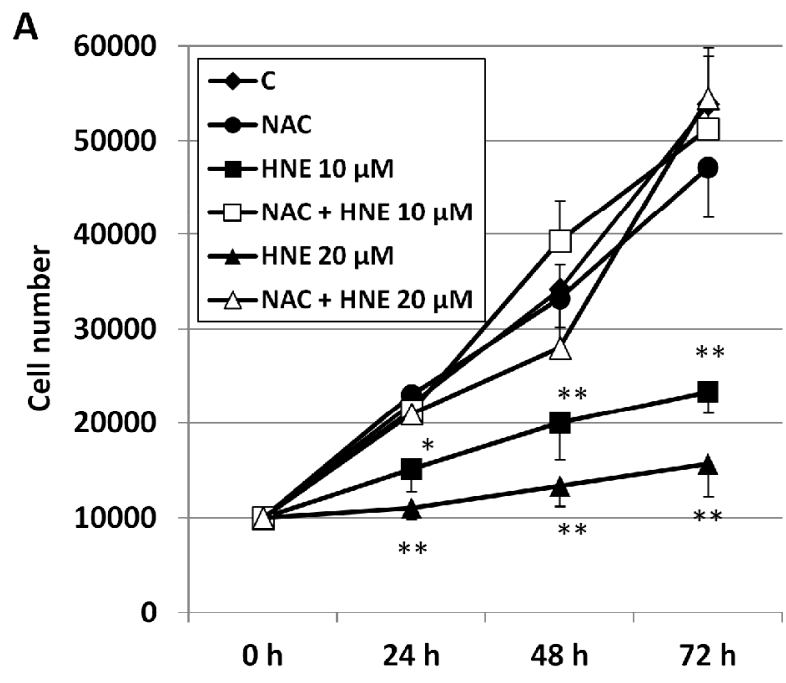

C
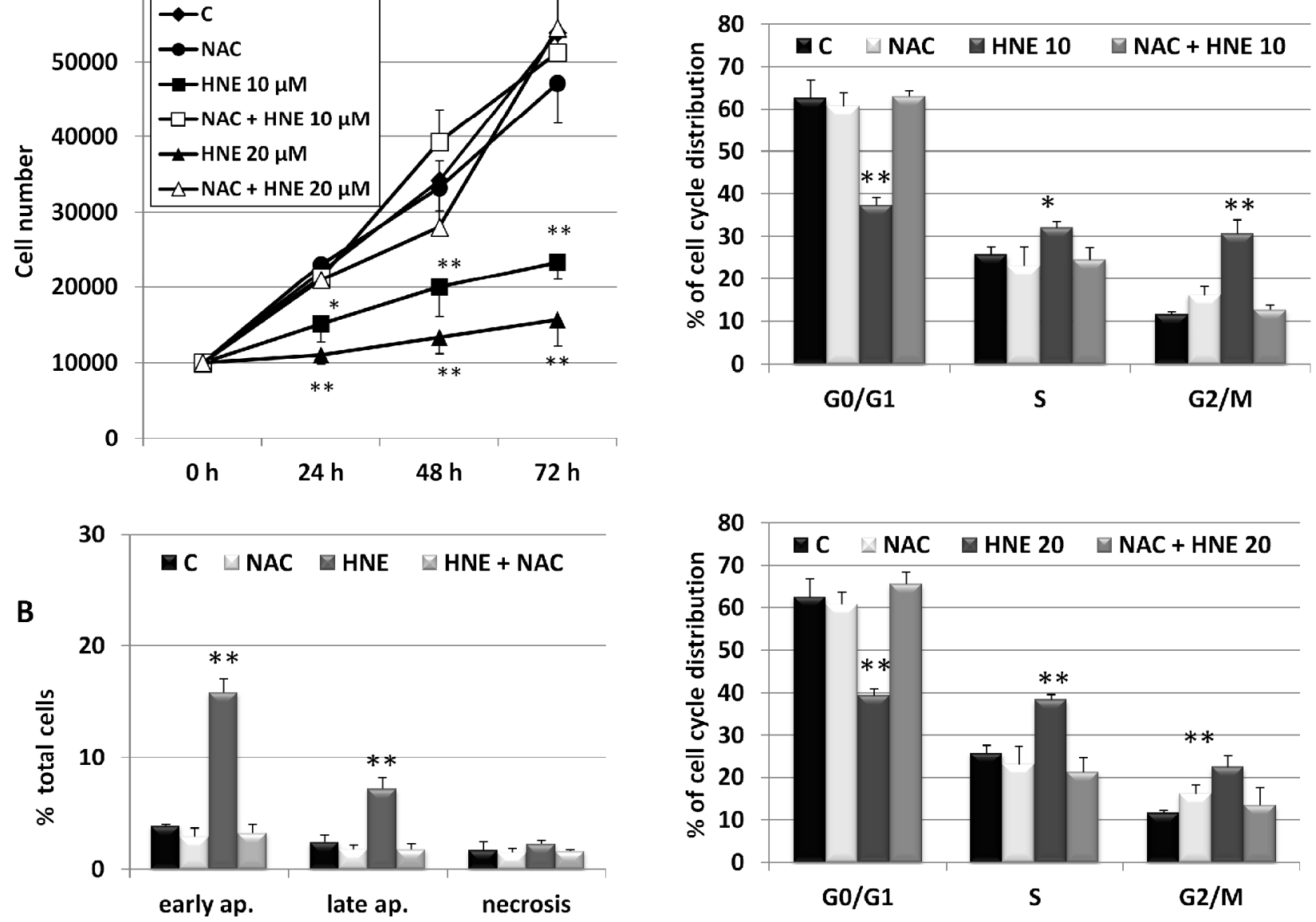

Fig 10

Fig 10 NAC prevented the inhibition of proliferation, the induction of apoptosis, and the G2/M accumulation elicited by HNE in T24 cells. Panel A: cell growth in T24 untreated (control, C) or treated cells with $5 \mathrm{mM}$ NAC; $10 \mu \mathrm{M}$ HNE; 5 mM NAC ( 2 h pretreatment $)+10 \mu \mathrm{M}$ HNE (NAC+ $10 \mu \mathrm{M} \mathrm{HNE}$ ); $20 \mu \mathrm{M} \mathrm{HNE} ; 5$ mM NAC ( 2 h pretreatment $)+20 \mu \mathrm{M}$ HNE (NAC+ $20 \mu \mathrm{M}$ HNE); Cells were seeded at 10,000 cells/well in 24-well plates, and cell number was evaluated daily by counting in a Bürker chamber. Data are the means \pm $\mathrm{SD}$ of three separate experiments, each performed in triplicate. *pOे..05 vs. C. **pờ.01 vs. C. Panel B: 
Cytofluorimetric analysis of annexin V/PI staining at $24 \mathrm{~h}$ in T24 cells untreated (Control, C), or treated cells with $5 \mathrm{mM}$ NAC; $20 \mu \mathrm{M}$ HNE (HNE); or $5 \mathrm{mM}$ NAC ( $2 \mathrm{~h}$ pretreatment) $+20 \mu \mathrm{M} \mathrm{HNE}$ (NAC+ HNE) at 24 h. Results show early apoptosis (annexin V-positive and PI-negative cells), late apoptosis (annexin Vpositive and PI-positive cells), and necrotic (annexin V-negative and PI-positive) cell population Results were expressed as means \pm SD of three independent experiments, each performed in duplicate. ${ }^{*}$ pÒ. $01 \mathrm{vs.}$ C. Panel C: Cell-cycle analysis of T24 untreated (control, C) or treated cells with $5 \mathrm{mM} \mathrm{NAC}, 20 \mu \mathrm{M} \mathrm{HNE}$

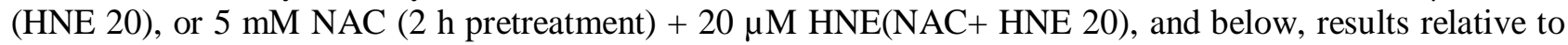
the $10 \mu \mathrm{M}$ HNE (HNE 10), or $5 \mathrm{mM}$ NAC ( $2 \mathrm{~h}$ pretreatment) $+10 \mu \mathrm{M}$ HNE(NAC+ HNE 10), $24 \mathrm{~h}$ after the treatments. The data were captured by using a BD Accuri Flow cytometer and analyzed by using FCS Express Plus. The relative percent of cell cycle distribution is shown. Data are the mean \pm SD of 3 separate experiments, each performed in duplicate.**pÒ.01 vs. C.
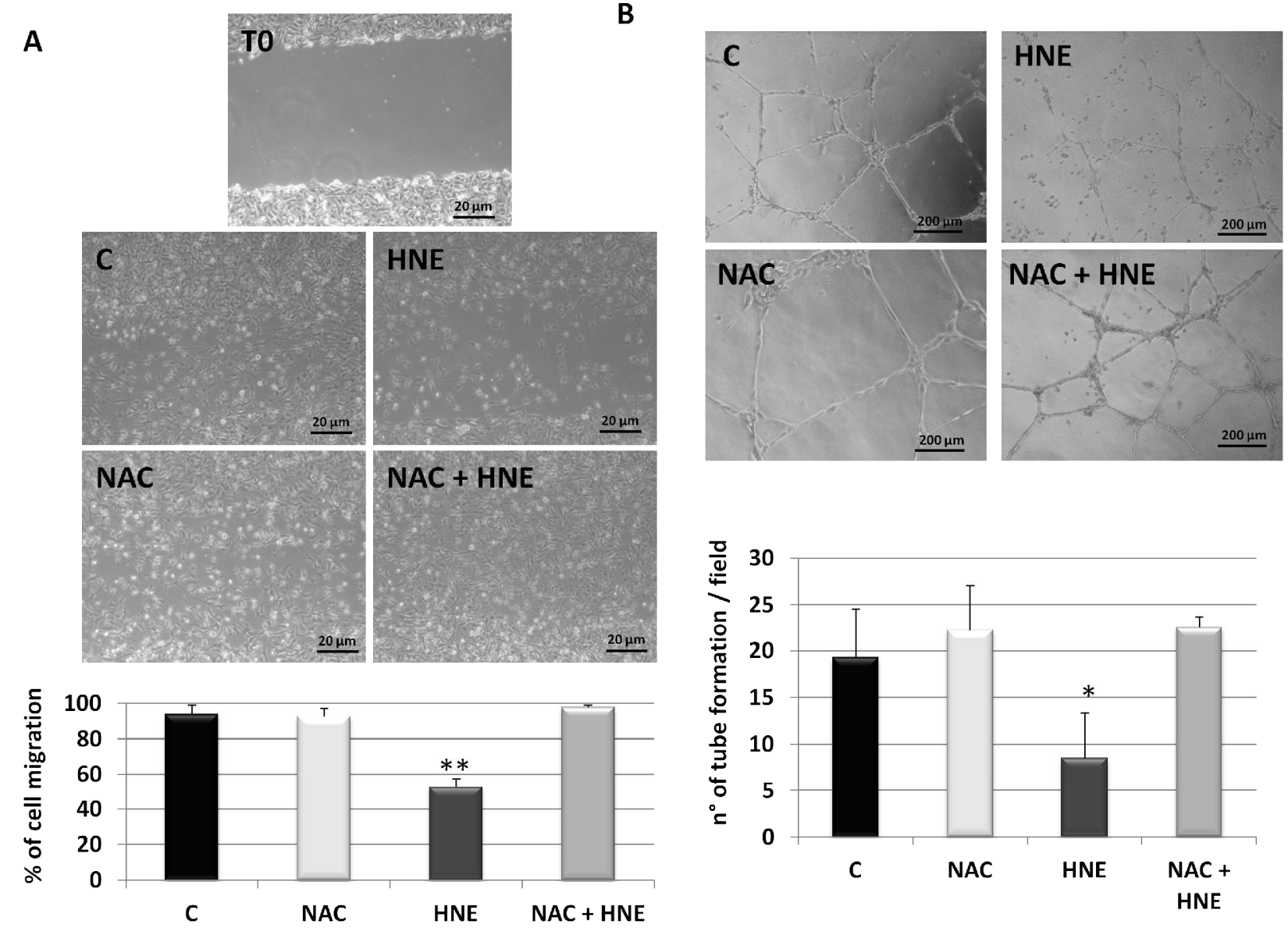

Fig 11

Fig. 11 NAC prevented the inhibition of cell migration and angiogenesis elicited by HNE in T24 cells. Panel A: wound healing assay at 0 (T0) and at $24 \mathrm{~h}$ in T24 cells untreated (C) or treated with $10 \mu \mathrm{M} \mathrm{HNE}$ (HNE), $5 \mathrm{mM}$ NAC, or treated cells with $5 \mathrm{mM}$ NAC $(2 \mathrm{~h}$ pretreatment $)+10 \mu \mathrm{M}$ HNE (NAC+ HNE). Below the 
quantification of wound healing is shown. The endpoint of the assay was measured by calculating the reduction in the width of the wound after $24 \mathrm{~h}$ and compared to T0 which is set at $100 \%$. The data are the mean \pm SD of three independent experiments. ${ }^{* *}$ p-valueOे.01 vs. C. Panel B: Tube formation assay on HUVEC after exposure to the conditioned media from untreated (C) or treated T24 cells as described in Panel A. Tube formation was then photographed after $6 \mathrm{~h}$ incubation with these conditioned media and evaluated by counting the total number of tubes in three wells; three different experiments were performed. The results are shown in the histogram below. The data are the mean \pm SD of three independent experiments. *p-valueÒ.05 vs. C.

\section{HNE inhibited YAP expression in T24 cells at a post-translational level}

To evaluate if the YAP protein content inhibition, elicited by HNE, was due to a reduction of YAP mRNA synthesis, YAP mRNA was analyzed through qRT-PCR (Fig. 12A) at 3h, $6 \mathrm{~h}$, and $24 \mathrm{~h}$ after the treatment with $20 \mu \mathrm{M}$ HNE in T24 cells. Since we didnô observe any down-regulation at any time, these results suggested that HNE action on YAP expression was at the post-translational level. In agreement with this hypothesis, we found an increase of the phosphorylated forms of YAP, pYAPser127 and pYAPser387 (Fig. 12B), as well as an increase of the ubiquitinated form of YAP in $20 \mu \mathrm{M}$ HNE-treated cells(Fig. 12C). These modifications occurred after $3 \mathrm{~h}$ of treatment, before the complete down-regulation of total YAP protein expression detected $6 \mathrm{~h}$ after the HNE treatment, as previous shown in Fig. 1A.The involvement of the proteasome in the control of YAP expression after HNE treatment was then demonstrated through the use of a proteasomal inhibitor MG132. Fig. 11D illustrated that the inhibition of YAP expression in $20 \mu \mathrm{M}$ HNE-treated cells was entirely abolished by a co-treatment with10 $\mu \mathrm{M}$ MG132 (Fig. 12D). 
A

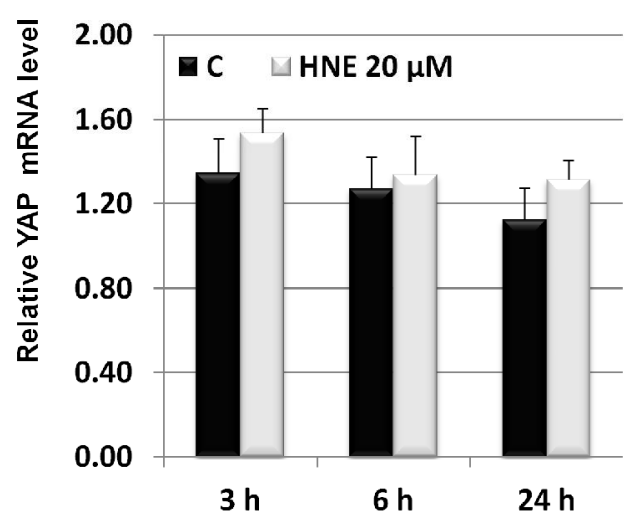

C

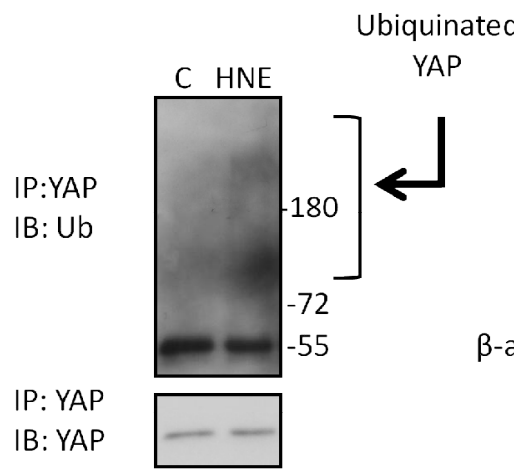

D
B

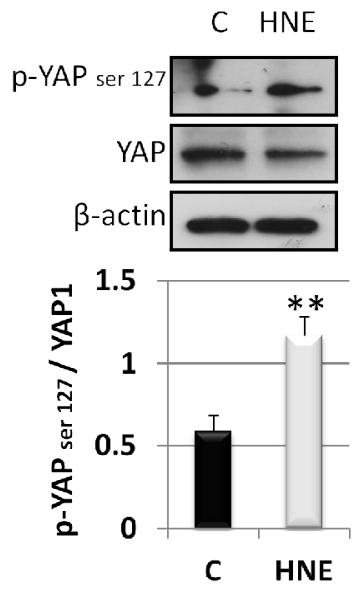

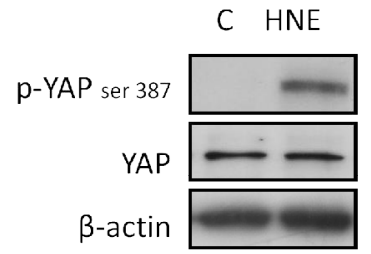

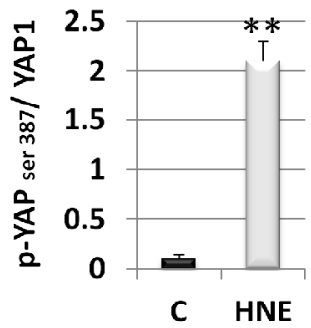

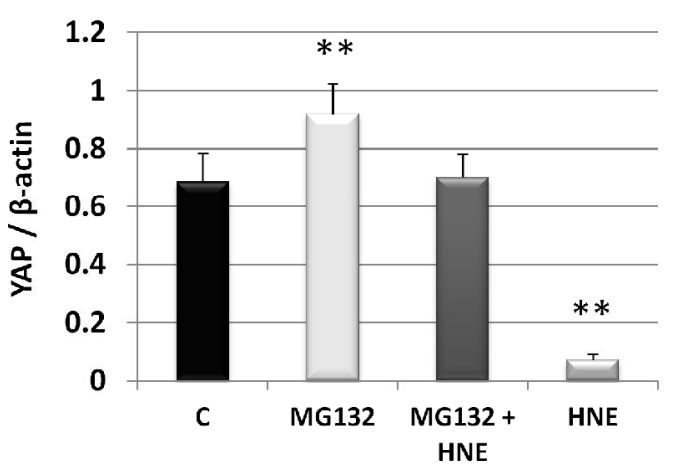

Fig 12

Fig 12: HNE inhibited YAP expression in T24 cells at a post-translational level. Panel A: YAP mRNA expression in untreated T24 cells (control, C) and treated with $20 \mu \mathrm{M} \mathrm{HNE}$ at the indicated time, evaluated by qRT-PCR. Abelson (Abl) gene was utilized as housekeeping control. Results showing a discrepancy greater than one cycle threshold in one of the wells were excluded. The results were analyzed using the gent method. Data are the mean \pm SD of 3 separate experiments, each performed in duplicate. Panel B: WB analysis of p-YAPser127 and p-YAPser387 in untreated control T24 cells (C) and $3 \mathrm{~h}$ after the treatment with $20 \mu \mathrm{M}$ HNE (HNE). YAP and b-actin were also analyzed for normalization of the results. Below quantification of protein products was performed by densitometric scanning, showing the ratio p-YAP/YAP normalized to the 6 -actin signal. Data are indicated as the mean \pm SD from three independent experiments. ** p-value Oे..01 vs. C. Panel C: YAP-Ubiquitin immunocomplexes in untreated T24 cells (control, C) and $3 \mathrm{~h}$ after the treatment with $20 \mu \mathrm{M}$ HNE. From total cell lysates,YAP-Ubiquitin immunocomplexes were immunoprecipitated (IP) with anti-YAP antibody and analyzed by immunoblotting (IB) with an antiUbiquitin (Ub) antibody. The same membrane was then exposed to the anti-YAP antibody. This is the result of one representative experiment from a series of three experiments with similar results (data not shown). Panel D:WB analysis of YAP in untreated (control, C) or treated T24 cells with $10 \mu \mathrm{M}$ MG132 (MG132); $10 \mu \mathrm{M}$ MG132 + $20 \mu \mathrm{MHNE}$ (MG132+HNE), or with $20 \mu \mathrm{M}$ HNE, collected $6 \mathrm{~h}$ after the treatment. Equal protein loading was confirmed by exposure of the membranes to the anti-b-actin antibody. On the right, the quantification of protein products was performed by densitometric scanning. Data were normalized using the b-actin signal and are indicated as the mean \pm SD from three independent experiments. ${ }^{*}$ p-value Oे.05 vs. C; ** p-value Oे.01 vs. C. 
Forced expression of YAP abolished the viability inhibition and the induction of apoptosis elicited by HNE.

The T24 cells were transiently transfected with YAP1 cDNA in pCMV6 vector. YAP gene expression was determined in untransfected cells (C) or $24 \mathrm{~h}$ after transfection with YAPIcDNA (YAP) or empty vector (V). As shown in Fig 13A, transfection with YAP1 cDNA significantly increased YAP expression at $24 \mathrm{~h}$ with respect to cells untransfected or transfected with the empty vector (Fig 12A). Moreover, transfection with both vectors didnâ affect cell viability up to $72 \mathrm{~h}$ (Fig. 13B). In forced YAP1 expressing cells, HNE was not more able to down-regulate its protein level, both after $6 \mathrm{~h}$, when 10 and $20 \mu \mathrm{M}$ HNE doses were able to reduce YAP expression and after $24 \mathrm{~h}$, when only the highest dose had an inhibitory effect (Fig. 13C). Functional experiments were also performed to study the YAPlover-expression effects on viability and apoptosis after HNEtreatments. As shown in Fig. 13D, the forced YAP1 expression abolished the inhibition of viability elicited by the aldehyde with both doses, at all the times tested ( 24 h, 48 h, 72 h). Moreover, the cleavage of the apoptotic marker PPAR, observed $24 \mathrm{~h}$ from the treatment with $20 \mu \mathrm{M}$ HNE (see also Fig. 3B), was abolished in forced YAP1 expressing cells. The transfection with YAP1 cDNA or with the empty vector alone didnâ cause any PARP cleavage (Fig 13E).
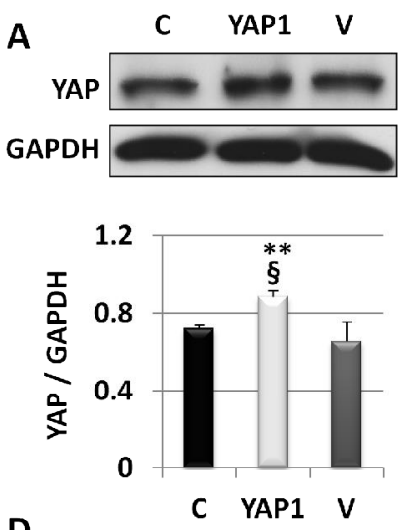

D

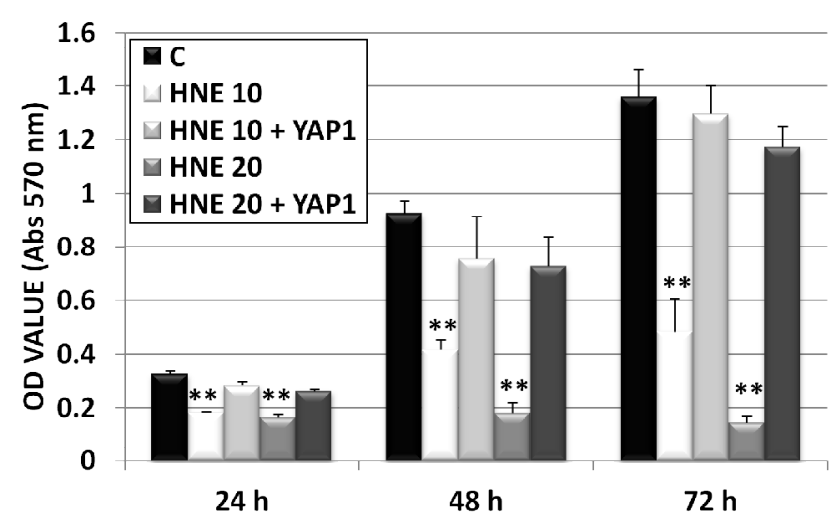

C

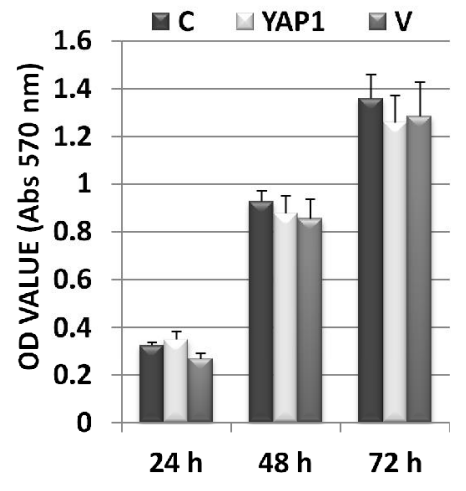

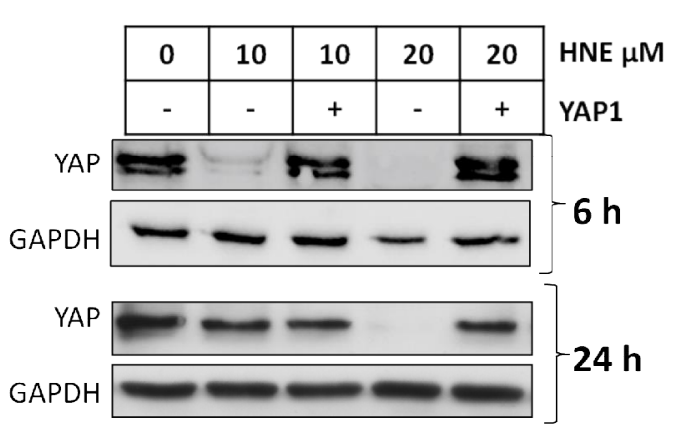

E

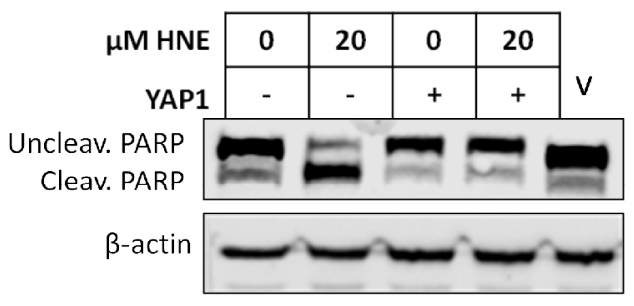

Fig 13 
Fig 13:Forced expression of YAP abolished the viability inhibition and the induction of apoptosis elicited by HNE. Panel A: WB analysis of YAP in T24 untransfected cells (C) or $24 \mathrm{~h}$ after transfection with YAP1 cDNA (YAP1) or empty vector (V). Equal protein loading was confirmed by exposure of the membranes to the anti-GAPDH antibody. Below the quantification of protein products was performed by densitometric scanning. Data were normalized using the GAPDH signal and are indicated as the mean \pm SD from three independent experiments. ** p-value Ô.01 vs. C; $\S p<0.05$ vs V. Panel B: MTT assay of T24 untransfected cells (C) or $24 \mathrm{~h}$ after transfection with YAP1 cDNA (YAP1) or empty vector (V). Results are the mean $\pm \mathrm{SD}$ of three separate experiments, each performed in quadruplicate. Panel C: WB analysis of YAP in T24 cells at $6 \mathrm{~h}$ and $24 \mathrm{~h}$ from the treatment with 10 or $20 \mu \mathrm{M}$ HNE in untransfected or YAP1 transfected cells. Equal protein loading was confirmed by exposure of the membranes to the anti-GAPDH antibody.This is the result of one representative experiment from a series of three with similar results (data not shown). Panel D: MTT assay of T24 untransfected and untreated cells (C), T24 untransfected cells treated with 10 (HNE 10) or 20 $\mu \mathrm{M}$ HNE (HNE 20) alone, or YAP1 transfected cells treated with 10 (HNE $10+$ YAP1) or $20 \mu \mathrm{M}$ HNE (HNE 20+YAP1). Data were normalized using the GAPDH signal and are indicated as the mean \pm SD from three independent experiments. ** p-value OO.01 vs. C. Panel E: WB analysis of total PARP (uncleaved and cleaved) in T24 cells untransfected, YAP1 transfected, or transfected with the empty vector (V), $24 \mathrm{~h}$ after the treatment with $20 \mu \mathrm{M}$ HNE cells. Equal protein loading was confirmed by exposure of the membranes to the anti- 6 -actin antibody.

This is the results of one representative experiment from a series of three with similar results (data not shown).

\section{Discussion}

The results presented in this experimental work underlines the ability of micromolar concentrations of HNE in modulating multiple signaling pathways involved in the anti-tumor response. The inhibition of Yap expression from the aldehyde in T24 bladder cancer cells, here reported for the first time, adds new insight into the comprehension of HNE action mechanisms. Moreover, we demonstrated that Yap inhibition occurred not only in T24 cells, but also in CRL2335 breast and A375 melanoma cells. HNE is therefore confirmed as a regulatory molecule of the Hippo pathway in several tumor lines.

In HNE-treated T24 cells, Yap protein expression inhibition was transient and concentration-dependent. After $6 \mathrm{~h}$ from the treatment this down-regulation was almost complete with both 10 and 20 عM HNE concentrations, while after $24 \mathrm{~h}$ the inhibition was present only with the highest dose. After $48 \mathrm{~h}$ and $72 \mathrm{~h}$ the expression was similar to the control. These results are in agreement with our previous results obtained on other oncogenes, where it was demonstrated that a single treatment with 10 عM HNE significantly inhibited the expression of c-myc, c-myb and cyclins D1/D2 within 4-8h, whereas after $24 \mathrm{~h}$ their expression increased up to the control values $[29,32,33]$. The reversibility of the inhibitory effect on gene expression displayed by HNE may be due to the short life of this aldehyde in the cell cultures [43]. The quick disappearance of HNE from the culture medium has been confirmed from results here reported (it disappears from the medium 
of HNE-treated cells within $1 \mathrm{~h}$ ), due to a heterogeneous set of biotransformations, including the GSH-clearance and several enzymatic reactions [44].

The HNE-induced YAP inhibition, albeit transitory, was however sufficient to downregulate the two target genes survivin and Cyr61. Both genes are involved in the regulation of various cell functions essential for the tumorigenesis process. Cyr 61, a cellular matrix protein, participates in regulating proliferation, cell cycle, angiogenesis, invasion, and metastasis [45]. Survivin belongs to the Inhibitor-of Ï Apoptosis Protein (IAP) family; it is expressed in the majority of malignancies, but not in the healthy tissue [46], correlating with higher resistance to chemotherapeutic treatments and an unfavorable prognosis [47]. Its anti-apoptotic activity occurs through its ability to bind and inhibit the activity of caspases 3, 7 and 9 [48]. However, the involvement of surviving has been demonstrated in other biological functions, such as cell cycle control or the promotion of angiogenesis, through the induction of the VEGF synthesis [47-48].

Yap inhibition paralleled to the reduction of the MTT values in all the cell lines studied. As mentioned in the result section, the MTT assay, by assessing the metabolic activity, can be a measure of both cell viability and cell proliferation; thus, we have investigated in T24 bladder cancer cells whether MTT inhibition was a result of cell cycle block or cell death induction. We found that $10 \mathrm{\varepsilon M} \mathrm{HNE}$ induced an accumulation of cells in the G2/M phase but not cell death, while, after the treatment with the higher concentration of HNE, the two events coexist: a modest, but significant, increase of the G2/M cells and an induction of apoptosis (around 20\%). From literature data, it is well-known that concentrations higher than 30 عM HNE induce cell death in a wide variety of tumor lines [49], while, with lower concentrations (HNE 1-20 عM), the effect of cell death was observed in some cell lines [50-53], but not in others [54-55]. Our results demonstrated that T24 cells have the apoptosis threshold ranged from 10 to $20 \mu \mathrm{M}$ HNE. The different susceptibilities of the various cell lines can be explained by a different HNE metabolizing capability, as well as by different levels of antioxidant defenses, such as GSH. For instance, in Caco-2 cells, where the treatment with $1 \mu \mathrm{M}$ HNE caused apoptosis [53], a level of GSH of about $35 \mathrm{nmol} / \mathrm{mg}$ of proteins has been reported [56], in T24 cells the GSH content was higher (about 50 $\mathrm{nmol} / \mathrm{mg}$ of proteins) [57], thus justifying a higher resistance to the HNE toxic effect.

The inhibition of MTT values paralleled to the inhibition of Ki67+ positive cells, as well as the number of cells counted by Bürker chamber after HNE treatments, and these effects largely corresponded to the accumulation of T24 cells in the G2/M phase of cell cyle. Literature data on the HNE ability to affect cell cycle show that this aldehyde can either increase the proportion of cells in G0/G1 and G2/M phases. For instance, HNE accumulated in the G0/G1 phase the leukemic and K562 cells [33-34], the SK-N-BE neuroblastoma cell lines [52], and the colon carcinoma RKO cells 
[58]. This accumulation was accompanied by a decrease in the expression of specific cyclins that control the G1/S phase, such as the cyclins D1, D2, and to A [33] or by an increased expression of the inhibitors of the cyclin/cyclin-dependent kinase (CDK) complexes, such as p21 WAF1/CIP1 $[34,52,59]$. Recently, it has also been demonstrated, in colon carcinoma RKO cells, that HNE can form a covalent adduct with CDK2, and that this adduction alters the enzyme activity, contributing in the cell cycle delay [58]. Conversely, in PC3 prostate carcinoma cells [23] or HepG2 hepatocarcinoma cells [60], the aldehyde was able to induce an accumulation in the G2/M phase. In HepG2 cells, this block, caused by treatment with 40 عM HNE, was accompanied by a decrease in the expression of CDK1 and cyclin B1 and an increase in p21 activity [60]. Our results in T24 cells are in agreement with these previous data and underline the ability of the aldehyde to affect the cell cycle progression.

Low doses of HNE ( 1 عM or less) generally can stimulate cellular migration, while higher concentrations can block it [61-64]. Our results obtained in T24 cells confirmed that concentrations of HNE greater than $1 \varepsilon M$ are generally inhibitory for this parameters. HNE could inhibit cell migration through the involvement of the inhibition of the Cyr61 gene, the YAP target involved in migration control.

10 عM HNE was also able to inhibit the angiogenic potential of T24 cells. This result was in agreement with literature data demonstrating that low HNE concentrations ( $1 \varepsilon \mathrm{M}$ or less) can induce tube formation [26, 65-66], while higher HNE concentrations (5-10 عM) have an opposite effect [26]. Thus, as previously observed in cell migration, HNE can be either anti- and proangiogenic depending on the HNE concentration used.

However, the inhibition of the tube-formation here reported cannot be ascribed to HNE directly, since it disappeared from the cell culture within $1 \mathrm{~h}$, thus, it could depend on the modulation of the factors secreted by the cells, with an imbalance between pro- and anti-angiogenic factors. Among these components, and in agreements with other reports [67], we have demonstrated an involvement of VEGF, since its expression was inhibited by HNE in T24 cells. Of note, a convergence has been demonstrated between the VEGF and YAP signalling: YAP is an effector of the VEGF signaling in developmental angiogenesis [68], and the pharmacological inhibition of the YAP-TEAD complex (i.e. verteporfin) can inhibit VEGF, likely through a mechanism involving TEAD via interaction with the Vestigial-like (Vgll) transcription coactivator [69]. Finally, in the inhibition of angiogenesis elicited by the aldehyde, we cannot exclude the involvement of canonical YAP signaling, through the modulation of its downstream targets survivin and Cyr61, both involved in angiogenesis. 
The hypothesis that HNE, as a pro-oxidant agent with anti-tumoral activity, could regulate the expression of YAP through a redox-dependent mechanism, has been confirmed. NAC treatment not only abolished the HNE effects on YAP expression and its targets, but also reduced the HNE effect on proliferation, apoptosis, cell cycle, migration, and angiogenesis.

The pro-oxidant activity of the HNE was not correlated with the expression inhibition of MnSOD, another recognized YAP-target, but mainly through the inhibition of the GSH content. Moreover, after NAC treatment we observed an important increase of GSH content, which completely prevented the GSH depletion caused by HNE. Our results are in agreement with previous reports showing the protective effect of NAC on HNE-induced apoptosis in several experimental models, such as the Jurkat leukaemic T-cell line [51], the intestinal epithelial cells [21], and the cerebellar granule cells [70]. Cells pre-treated with NAC, increasing their GSH content, can better scavenge HNE, leading to the lack of formation of HNE-protein adducts, crucial to determining its activity [11, 70-72]. Moreover, the protection by NAC may also depend on its scavenger action directly toward HNE, since the two molecules can form a stable bond [73].

Finally, we demonstrated that the inhibition of YAP expression by HNE was dependent on the increase of YAP degradation. Indeed, after HNE treatments, we found an increased of the two phosphorylated forms of YAP studied, p-YAPser127 and p-YAPser387 and an increase of the ubiquitinated form of YAP. The involvement of the proteasome in the YAP protein reduction, elicited by the aldehyde, was also demonstrated by using the MG132 proteasome inhibitor, that abolished the HNE-induced YAP down-regulation.

The involvement of YAP in several biological effect displayed by HNE in T24 cells was demonstrated by forcing YAP expression. In T24 cells, in which YAP was up-regulated, HNE did not reduced cell growth and did not induce apoptosis.

In conclusion, our data indicate that HNE can post-translationally down-regulate YAP through a redox-dependent mechanism and that this modulation can contribute in determining the anti-tumoral effects of HNE.

\section{Acknowledgement}

We thank the Pathology Unit and the Obstetrics and Gynecology Unit, Martini Hospital (Turin, Italy), for providing human umbilical cords.

This work was supported by the University of Turin (local fund to RA, CD, GB, and SP), and by Fondazione Amici di Jean. 


\section{References}

[1] Harvey, K.F.; Zhang, X.; Thomas, D.M. The Hippo pathway and human cancer. Nature Reviews Cancer 13: 246ï 257; 2013. https://doi.org/10.1038/nrc3458

[2] Zhao, B.; Wei, X.; Li, W.; Udan, R.S.; Yang, Q.; Kim, J.; Xie, J.; Ikenoue, T.; Yu, J.; Li, L.; Zheng, P.; Ye, K.; Chinnaiyan, A.; Halder, G.; Lai, Z.-C.; Guan, K.-L. Inactivation of YAP oncoprotein by the Hippo pathway is involved in cell contact inhibition and tissue growth control. Genes Dev. 21: 2747ї 2761; 2007. https://doi.org/10.1101/gad.1602907

[3] Zhao, B.; Li, L.; Tumaneng, K.; Wang, C.-Y.; Guan, K.-L. A coordinated phosphorylation by Lats and CK1 regulates YAP stability through SCF6-TRCP. Genes Dev. 24: 72ï 85; 2010. https://doi.org/10.1101/gad.1843810

[4] Dong, J.; Feldmann, G.; Huang, J.; Wu, S.; Zhang, N.; Comerford, S.A.; Gayyed, M.F.; Anders, R.A.; Maitra, A.; Pan, D. Elucidation of a Universal Size-Control Mechanism in Drosophila and Mammals. Cell 130: 1120ї 1133; 2007. https://doi.org/10.1016/j.cell.2007.07.019

[5] Zhang, J.; Smolen, G.A.; Haber, D.A. Negative regulation of YAP by LATS1 underscores evolutionary conservation of the Drosophila Hippo pathway. Cancer Res. 68: 2789ï 2794; 2008. https://doi.org/10.1158/0008-5472.CAN-07-6205

[6] Zhao, B.; Ye, X.; Yu, Jindan, Li, L.; Li, W.; Li, S.; Yu, Jianjun, Lin, J.D.; Wang, C.-Y.; Chinnaiyan, A.M.; Lai, Z.-C.; Guan, K.-L. TEAD mediates YAP-dependent gene induction and growth control. Genes Dev. 22: 1962ї 1971; 2008. https://doi.org/10.1101/gad.1664408

[7] Lu, L.; Li, Y.; Kim, S.M.; Bossuyt, W.; Liu, P.; Qiu, Q.; Wang, Y.; Halder, G.; Finegold, M.J.; Lee, J.-S.; Johnson, R.L. Hippo signaling is a potent in vivo growth and tumor suppressor pathway in the mammalian liver. Proc. Natl. Acad. Sci. U.S.A. 107: 1437ï 1442; 2010. https://doi.org/10.1073/pnas.0911427107

[8] Moroishi, T.; Hansen, C.G.; Guan, K.-L. The emerging roles of YAP and TAZ in cancer. Nat Rev Cancer 15: 73ї 79; 2015. https://doi.org/10.1038/nrc3876

[9] Yu, F.-X.; Zhao, B.; Guan, K.-L. Hippo Pathway in Organ Size Control, Tissue Homeostasis, and Cancer. Cell 163: 811ї 828; 2015. https://doi.org/10.1016/j.cell.2015.10.044

[10] Moon, S.; Yeon Park, S.; Woo Park, H. Regulation of the Hippo pathway in cancer biology. Cell. Mol. Life Sci. 75: 2303ї 2319; 2018. https://doi.org/10.1007/s00018-018-2804-1

[11] Wang, Y.; Dong, Q.; Zhang, Q.; Li, Z.; Wang, E.; Qiu, X. Overexpression of yes-associated protein contributes to progression and poor prognosis of non-small-cell lung cancer. Cancer Science 101: 1279ї 1285; 2010. https://doi.org/10.1111/j.1349-7006.2010.01511.x

[12] Maugeri-Saccà, M.; De Maria, R. The Hippo pathway in normal development and cancer. Pharmacol. Ther. 186: 60ї 72; 2018. https://doi.org/10.1016/j.pharmthera.2017.12.011 
[13] Liu, J.-Y.; Li, Y.-H.; Lin, H.-X.; Liao, Y.-J.; Mai, S.-J.; Liu, Z.-W.; Zhang, Z.-L.; Jiang, L.J.; Zhang, J.-X.; Kung, H.-F.; Zeng, Y.-X.; Zhou, F.-J.; Xie, D. Overexpression of YAP 1 contributes to progressive features and poor prognosis of human urothelial carcinoma of the bladder. BMC Cancer 13: 349; 2013. https://doi.org/10.1186/1471-2407-13-349

[14] Ciamporcero, E.; Shen, H.; Ramakrishnan, S.; Yu Ku, S.; Chintala, S.; Shen, L.; Adelaiye, R.; Miles, K.M.; Ullio, C.; Pizzimenti, S.; Daga, M.; Azabdaftari, G.; Attwood, K.; Johnson, C.; Zhang, J.; Barrera, G.; Pili, R. YAP activation protects urothelial cell carcinoma from treatmentinduced DNA damage. Oncogene 35: 1541ї 1553; 2016. https://doi.org/10.1038/onc.2015.219

[15] Wu, H.; Xiao, Y.; Zhang, S.; Ji, S.; Wei, L.; Fan, F.; Geng, J.; Tian, J.; Sun, X.; Qin, F.; Jin, C.; Lin, J.; Yin, Z.-Y.; Zhang, T.; Luo, L.; Li, Y.; Song, S.; Lin, S.-C.; Deng, X.; Camargo, F.; Avruch, J.; Chen, L.; Zhou, D. The Ets transcription factor GABP is a novel component of the Hippo pathway essential for growth and antioxidant defense. Cell Rep. 3; 2013. https://doi.org/10.1016/j.celrep.2013.04.020

[16] Ciamporcero, E.; Daga, M.; Pizzimenti, S.; Roetto, A.; Dianzani, C.; Compagnone, A.; Palmieri, A.; Ullio, C.; Cangemi, L.; Pili, R.; Barrera, G. Crosstalk between Nrf2 and YAP contributes to maintaining the antioxidant potential and chemoresistance in bladder cancer. Free Radic. Biol. Med. 115: 447ï 457; 2018. https://doi.org/10.1016/j.freeradbiomed.2017.12.005

[17] Shao, D.; Zhai, P.; Del Re, D.P.; Sciarretta, S.; Yabuta, N.; Nojima, H.; Lim, D.-S.; Pan, D.; Sadoshima, J. A functional interaction between Hippo-YAP signalling and FoxO1 mediates the oxidative stress response. Nat. Commun. 5: 3315; 2014. https://doi.org/10.1038/ncomms4315

[18] Tao, G.; Kahr, P.C.; Morikawa, Y.; Zhang, M.; Rahmani, M.; Heallen, T.R.; Li, L.; Sun, Z.; Olson, E.N.; Amendt, B.A.; Martin, J.F. Pitx2 promotes heart repair by activating the antioxidant response after cardiac injury. Nature 534: 119ї 123; 2016. https://doi.org/10.1038/nature17959

[19] Barrera, G.; Pizzimenti, S.; Dianzani, M.U. Lipid peroxidation: control of cell proliferation, cell differentiation and cell death. Mol. Aspects Med. 29: 1ї 8; 2008. https://doi.org/10.1016/j.mam.2007.09.012

[20] Esterbauer, H.; Schaur, R.J.; Zollner, H. Chemistry and biochemistry of 4-hydroxynonenal, malonaldehyde and related aldehydes. Free Radic. Biol. Med. 11: 81ї 128; 1991.

[21] Ji, Y.; Dai, Z.; Wu, G.; Wu, Z. 4-Hydroxy-2-nonenal induces apoptosis by activating ERK1/2 signaling and depleting intracellular glutathione in intestinal epithelial cells. Scientific Reports 6: 32929; 2016. https://doi.org/10.1038/srep32929

[22] Pillon, N.J.; Croze, M.L.; Vella, R.E.; Soulère, L.; Lagarde, M.; Soulage, C.O. The Lipid Peroxidation By-Product 4-Hydroxy-2-Nonenal (4-HNE) Induces Insulin Resistance in Skeletal Muscle through Both Carbonyl and Oxidative Stress. Endocrinology 153: 2099101211 ; 2012. 
https://doi.org/10.1210/en.2011-1957

[23] Pettazzoni, P.; Pizzimenti, S.; Toaldo, C.; Sotomayor, P.; Tagliavacca, L.; Liu, S.; Wang, D.; Minelli, R.; Ellis, L.; Atadja, P.; Ciamporcero, E.; Dianzani, M.U.; Barrera, G.; Pili, R. Induction of cell cycle arrest and DNA damage by the HDAC inhibitor panobinostat (LBH589) and the lipid peroxidation end product 4-hydroxynonenal in prostate cancer cells. Free Radic. Biol. Med. 50: 313ї 322; 2011. https://doi.org/10.1016/j.freeradbiomed.2010.11.011

[24] Pizzimenti, S.; Toaldo, C.; Pettazzoni, P.; Dianzani, M.U.; Barrera, G.; The ñtwo-facedò effects of reactive oxygen species and the lipid peroxidation product 4-hydroxynonenal in the hallmarks of cancer. Cancers (Basel) 2: 338ї 363; 2010b. https://doi.org/10.3390/cancers2020338

[25] Gentile, F.; Pizzimenti, S.; Arcaro, A.; Pettazzoni, P.; Minelli, R.; DôAngelo, D.; Mamone, G.; Ferranti, P.; Toaldo, C.; Cetrangolo, G.; Formisano, S.; Dianzani, M.U.; Uchida, K.; Dianzani, C.; Barrera, G. Exposure of HL-60 human leukaemic cells to 4-hydroxynonenal promotes the formation of adduct(s) with alpha-enolase devoid of plasminogen binding activity. Biochem. J. 422: 285ï 294; 2009. https://doi.org/10.1042/BJ20090564

[26] Stagos, D.; Zhou, H.; Ross, D.; Vasiliou, V. 4-HNE inhibits tube formation and up-regulates chondromodulin-I in human endothelial cells. Biochem. Biophys. Res. Commun. 379: 654ї 658; 2009a. https://doi.org/10.1016/j.bbrc.2008.11.095

[27] Gasparovic, A.C.; Milkovic, L.; Sunjic, S.B.; Zarkovic, N.; Cancer growth regulation by 4hydroxynonenal. Free Radic. Biol. Med. 111: 226ї 234; 2017. https://doi.org/10.1016/j.freeradbiomed.2017.01.030

[28] Fazio, V.M.; Barrera, G.; Martinotti, S.; Farace, M.G.; Giglioni, B.; Frati, L.; Manzari, V.; Dianzani, M.U. 4-Hydroxynonenal, a product of cellular lipid peroxidation, which modulates c-myc and globin gene expression in K562 erythroleukemic cells. Cancer Res. 52: 4866ï 4871; 1992.

[29] Barrera, G.; Muraca, R.; Pizzimenti, S.; Serra, A.; Rosso, C.; Saglio, G.; Farace, M.G.; Fazio, V.M.; Dianzani, M.U. Inhibition of c-myc expression induced by 4-hydroxynonenal, a product of lipid peroxidation, in the HL-60 human leukemic cell line. Biochem. Biophys. Res. Commun. 203: 553ї 561; 1994.https://doi.org/10.1006/bbrc.1994.2218

[30] Rinaldi, M.; Barrera, G.; Aquino, A.; Spinsanti, P.; Pizzimenti, S.; Farace, M.G.; Dianzani, M.U.; Fazio, V.M. 4-Hydroxynonenal-induced MEL cell differentiation involves PKC activity translocation. Biochem. Biophys. Res. Commun. 272: 75ї 80; 2000. https://doi.org/10.1006/bbrc.2000.2691

[31] Pizzimenti, S.; Briatore, F.; Laurora, S.; Toaldo, C.; Maggio, M.; De Grandi, M.; Meaglia, L.; Menegatti, E.; Giglioni, B.; Dianzani, M.U.; Barrera, G. 4-Hydroxynonenal inhibits telomerase activity and hTERT expression in human leukemic cell lines. Free Radic. Biol. Med. 40: 1578ї 
1591;2006. https://doi.org/10.1016/j.freeradbiomed.2005.12.024

[32] Barrera, G.; Pizzimenti, S.; Serra, A.; Ferretti, C.; Fazio, V.M.; Saglio, G.; Dianzani, M.U. 4-hydroxynonenal specifically inhibits c-myb but does not affect c-fos expressions in HL-60 cells. Biochem. Biophys. Res. Commun. 227: 589ï 593; 1996. https://doi.org/10.1006/bbrc.1996.1550

[33] Pizzimenti, S.; Barrera, G.; Dianzani, M.U.; Brüsselbach, S. Inhibition of D1, D2, and Acyclin expression in HL-60 cells by the lipid peroxydation product 4-hydroxynonenal. Free Radic. Biol. Med. 26:1578ї 1586; 1999.

[34] Skorokhod, O.A.; Caione, L.; Marrocco, T.; Migliardi, G.; Barrera, V.; Arese, P.; Piacibello, W.; Schwarzer, E. Inhibition of erythropoiesis in malaria anemia: role of hemozoin and hemozoingenerated 4-hydroxynonenal. Blood 116: 4328ї 4337; 2010. https://doi.org/10.1182/blood-2010-03272781

[35] Pizzimenti, S.; Menegatti, E.; Berardi, D.; Toaldo, C.; Pettazzoni, P.; Minelli, R.; Giglioni, B.; Cerbone, A.; Dianzani, M.U.; Ferretti, C.; Barrera, G. 4-hydroxynonenal, a lipid peroxidation product of dietary polyunsaturated fatty acids, has anticarcinogenic properties in colon carcinoma cell lines through the inhibition of telomerase activity. J. Nutr. Biochem. 21: 818ї 826; 2010a. https://doi.org/10.1016/j.jnutbio.2009.06.005

[36] Pizzimenti, S.; Barrera, G.; Calzavara, E.; Mirandola, L.; Toaldo, C.; Dianzani, M.U.; Comi, P.; Chiaramonte, R. Down-regulation of Notch1 expression is involved in HL-60 cell growth inhibition induced by 4-hydroxynonenal, a product of lipid peroxidation. Med. Chem. 4: 551ї 557; 2008.

[37] Sylvester, P.W. Optimization of the Tetrazolium Dye (MTT) Colorimetric Assay for Cellular Growth and Viability, in: Satyanarayanajois, S.D. (Ed.), Drug Design and Discovery: Methods and Protocols, Methods in Molecular Biology. Humana Press, Totowa, NJ, pp. 157ї 168; 2011. https://doi.org/10.1007/978-1-61779-012-6_9

[38] Dianzani, C.; Minelli, R.; Gigliotti, C.L.; Occhipinti, S.; Giovarelli, M.; Conti, L.; Boggio, E.; Shivakumar, Y.; Baldanzi, G.; Malacarne, V.; Orilieri, E.; Cappellano, G.; Fantozzi, R.; Sblattero, D.; Yagi, J.; Rojo, J.M.; Chiocchetti, A. Dianzani, U.; B7h triggering inhibits the migration of tumor cell lines. J. Immunol. 192: 4921ї4931; 2014. https://doi.org/10.4049/jimmunol.1300587

[39] Schneider, C.A.; Rasband, W.S.; Eliceiri, K.W. NIH Image to ImageJ: 25 years of image analysis. Nat. Methods 9: 671ї 675; 2012.

[40] Daga, M.; Ullio, C.; Argenziano, M.; Dianzani, C.; Cavalli, R.; Trotta, F.; Ferretti, C.; Zara, G.P.; Gigliotti, C.L. Ciamporcero, E.S.; Pettazzoni, P.; Corti, D.; Pizzimenti, S.; Barrera, G.; GSHtargeted nanosponges increase doxorubicin-induced toxicity ñin vitroò and ñin vivoò in cancer cells 
with high antioxidant defenses. Free Radic. Biol. Med. 97: 24ї 37; 2016. https://doi.org/10.1016/j.freeradbiomed.2016.05.009

[41] Livak, K.J.; Schmittgen, T.D. Analysis of relative gene expression data using real-time quantitative PCR and the 2(-Delta Delta C(T)) Method. Methods 25: 402ï 408; 2001.

[42] Simile, M.M.; Latte, G.; Demartis, M.I.; Brozzetti, S.; Calvisi, D.F.; Porcu, A.; Feo, C.F.; Seddaiu, M.A.; Daino, L.; Berasain, C.; Tomasi, M.L.; Avila, M.A.; Feo, F.; Pascale, R.M. Posttranslational deregulation of YAP1 is genetically controlled in rat liver cancer and determines the fate and stem-like behavior of the human disease. Oncotarget 7:49194-49216; 2016.

[43] Barrera, G.; Di Mauro, C.; Muraca, R.; Ferrero, D.; Cavalli, G.; Fazio, V.M.; Paradisi, L.; Dianzani, M.U. Induction of differentiation in human HL-60 cells by 4-hydroxynonenal, a product of lipid peroxidation. Exp. Cell Res. 197: 148ї 152; 1991. https://doi.org/10.1016/00144827(91)90416-R

[44] Mol, M.; Regazzoni, L.; Altomare, A.; Degani, G.; Carini, M.; Vistoli, G.; Aldini, G.; Enzymatic and non-enzymatic detoxification of 4-hydroxynonenal: Methodological aspects and biological consequences. Free Radic. Biol. Med. 111: 328ї 344; 2017. https://doi.org/10.1016/j.freeradbiomed.2017.01.036

[45] Lau, L.F. CCN1/CYR61: the very model of a modern matricellular protein. Cell. Mol. Life Sci. 68: 3149ї 3163; 2011. https://doi.org/10.1007/s00018-011-0778-3

[46] Cheung, C.H.A.; Huang, C.-C.; Tsai, F.-Y.; Lee, J.Y.-C.; Cheng, S.M.; Chang, Y.-C.; Huang, Y.-C.; Chen, S.-H.; Chang, J.-Y. Survivin - biology and potential as a therapeutic target in oncology. Onco Targets Ther. 6: 1453ї 1462; 2013. https://doi.org/10.2147/OTT.S33374

[47] Chen, X.; Duan, N.; Zhang, C.; Zhang, W. Survivin and Tumorigenesis: Molecular Mechanisms and Therapeutic Strategies. J. Cancer 7: 314 ï 323; 2016. https://doi.org/10.7150/jca.13332

[48] Sanhueza, C.; Wehinger, S.; Castillo Bennett, J.; Valenzuela, M.; Owen, G.I.; Quest, A.F.G.; The twisted survivin connection to angiogenesis. Mol. Cancer 14: 198; 2015. https://doi.org/10.1186/s12943-015-0467-1

[49] Csala, M.; Kardon. T.; Legeza, B.; Lizák, B.; Mandl, J.; Margittai, É.; Puskás, F.; Száraz, P.; Szelényi, P.; Bánhegyi, G. On the role of 4-hydroxynonenal in health and disease. Biochim. Biophys. Acta 1852: 826ï 838; 2015. https://doi.org/10.1016/j.bbadis.2015.01.015

[50] Kruman, I.; Bruce-Keller, A.J.; Bredesen, D.; Waeg, G.; Mattson, M.P. Evidence that 4hydroxynonenal mediates oxidative stress-induced neuronal apoptosis. J. Neurosci. 17: 5089ї 5100; 1997.

[51] Liu, W.; Kato, M.; Akhand, A.A.; Hayakawa, A.; Suzuki, H.; Miyata, T.; Kurokawa, K.; 
Hotta, Y.; Ishikawa, N.; Nakashima, I. 4-hydroxynonenal induces a cellular redox status-related activation of the caspase cascade for apoptotic cell death. J. Cell. Sci. 113: 635ï 641; 2000.

[52] Laurora, S.; Tamagno, E.; Briatore, F.; Bardini, P.; Pizzimenti, S.; Toaldo, C.; Reffo, P.; Costelli, P.; Dianzani, M.U.; Danni, O.; Barrera, G. 4-Hydroxynonenal modulation of p53 family gene expression in the SK-N-BE neuroblastoma cell line. Free Radic. Biol. Med. 38: 215ï 225; 2005. https://doi.org/10.1016/j.freeradbiomed.2004.10.014

[53] Cerbone, A.; Toaldo, C.; Laurora, S.; Briatore, F.; Pizzimenti, S.; Dianzani, M.U.; Ferretti, C.; Barrera, G. 4-Hydroxynonenal and PPARgamma ligands affect proliferation, differentiation, and apoptosis in colon cancer cells. Free Radic. Biol. Med. 42: 1661ї 1670; 2007. https://doi.org/10.1016/j.freeradbiomed.2007.02.009

[54] Pizzimenti, S.; Laurora, S.; Briatore, F.; Ferretti, C.; Dianzani, M.U.; Barrera, G. Synergistic effect of 4-hydroxynonenal and PPAR ligands in controlling human leukemic cell growth and differentiation. Free Radic. Biol. Med. 32: 233ї 245; 2002.

[55] Pizzimenti, S.; Ciamporcero, E.; Pettazzoni, P.; Osella-Abate, S.; Novelli, M.; Toaldo, C.; Husse, M.; Daga, M.; Minelli, R.; Bisazza, A.; Ferruti, P.; Ranucci, E.; Grazia Bernengo, M.; Dianzani, C.; Biasi, F.; Cavalli, R.; Barrera, G. The inclusion complex of 4-hydroxynonenal with a polymeric derivative of 6-cyclodextrin enhances the antitumoral efficacy of the aldehyde in several tumor cell lines and in a three-dimensional human melanoma model. Free Radic. Biol. Med. 65: 765ï 777; 2013. https://doi.org/10.1016/j.freeradbiomed.2013.06.035

[56] Napolitano, M.; Rainaldi, G.; Bravo, E.; Rivabene, R. Influence of thiol balance on micellar cholesterol handling by polarized Caco-2 intestinal cells. FEBS Lett. 551: 165ї 170; 2003.

[57] Kimiya, K.; Naito, S.; Soejima, T.; Sakamoto, N.; Kotoh, S.; Kumazawa, J.; Tsuruo, T.; Establishment and characterization of doxorubicin-resistant human bladder cancer cell line, KK47/ADM. J. Urol. 148:441ї 445;1992.

[58] Camarillo, J.M.; Rose, K.L.; Galligan, J.J.; Xu, S.; Marnett, L.J. Covalent Modification of CDK2 by 4-Hydroxynonenal as a Mechanism of Inhibition of Cell Cycle Progression. Chem. Res. Toxicol. 29: 323ї 332; 2016. https://doi.org/10.1021/acs.chemrestox.5b00485

[59] Barrera, G.; Pizzimenti, S.; Laurora, S.; Moroni, E.; Giglioni, B.; Dianzani, M.U. 4Hydroxynonenal affects pRb/E2F pathway in HL-60 human leukemic cells. Biochem. Biophys. Res. Commun. 295: 267ї 275; 2002.

[60] Chaudhary, P.; Sharma, R.; Sahu, M.; Vishwanatha, J.K.; Awasthi, S.; Awasthi, Y.C. 4Hydroxynonenal induces G2/M phase cell cycle arrest by activation of the ataxia telangiectasia mutated and Rad3-related protein (ATR)/checkpoint kinase 1 (Chk1) signaling pathway. J. Biol. Chem. 288: 20532ї 20546; 2013. https://doi.org/10.1074/jbc.M113.467662 
[61] Curzio, M.; Torrielli, M.V.; Giroud, J.P.; Esterbauer, H.; Dianzani, M.U. Neutrophil chemotactic responses to aldehydes. Res. Commun. Chem. Pathol. Pharmacol. 36: 463ï 476; 1982. [62] Curzio, M.; Ferretti, C.; Stephens, R.J.; Esterbauer, H.; Dianzani, M.U. Binding of the lipid peroxidation product 4-hydroxynonenal to human polymorphonuclear leukocytes. Cell Biochem. Funct. 12: 57ї 62; 1994. https://doi.org/10.1002/cbf.290120108

[63] Müller, K.; Hardwick, S.J.; Marchant, C.E.; Law, N.S.; Waeg, G.; Esterbauer, H.; Carpenter, K.L.H.; Mitchinson, M.J. Cytotoxic and chemotactic potencies of several aldehydic components of oxidised low density lipoprotein for human monocyte-macrophages. FEBS Letters 388: 165ï 168; 1996. https://doi.org/10.1016/0014-5793(96)00559-5

[64] Vatsyayan, R.; Chaudhary, P.; Sharma, A.; Sharma, R.; Rao Lelsani, P.C.; Awasthi, S.; Awasthi, Y.C. Role of 4-hydroxynonenal in epidermal growth factor receptor-mediated signaling in retinal pigment epithelial cells. Exp. Eye Res. 92: 147ї 154; 2011. https://doi.org/10.1016/j.exer.2010.11.010

[65] Vatsyayan, R.; Lelsani, P.C.R.; Chaudhary, P.; Kumar, S.; Awasthi, S.; Awasthi, Y.C.; The expression and function of vascular endothelial growth factor in retinal pigment epithelial (RPE) cells is regulated by 4-hydroxynonenal (HNE) and glutathione S-transferaseA4-4. Biochem. Biophys. Res. Commun. 417: 346ï 351; 2012. https://doi.org/10.1016/j.bbrc.2011.11.113

[66] Li, Y.-P.; Tian, F.-G.; Shi, P.-C.; Guo, L.-Y.; Wu, H.-M.; Chen, R.-Q.; Xue, J.-M. 4Hydroxynonenal promotes growth and angiogenesis of breast cancer cells through HIF-1Ŭ stabilization. Asian Pac. J. Cancer Prev. 15: 10151ї 10156; 2014.

[67] Ayalasomayajula, S.P.; Kompella, U.B. Induction of vascular endothelial growth factor by 4-hydroxynonenal and its prevention by glutathione precursors in retinal pigment epithelial cells. Eur. J. Pharmacol. 449:213-220; 2002.

[68] Elaimy, A.L.; Mercurio, A.M. Convergence of VEGF and YAP/TAZ signaling: Implications for angiogenesis and cancer biology. Sci Signal. 11(552); 2018.

[69] Brodowska, K.; Al-Moujahed, A.; Marmalidou, A.; Meyer Zu Horste, M.; Cichy, J.; Miller, J.W.; Gragoudas, E.; Vavvas, D.G. The clinically used photosensitizer Verteporfin (VP) inhibits YAP-TEAD and human retinoblastoma cell growth in vitro without light activation. Exp. Eye Res. $124: 67-73 ; 2014$.

[70] Arakawa, M.; Ishimura, A.; Arai, Y.; Kawabe, K.; Suzuki, S.; Ishige, K.; Ito, Y. NAcetylcysteine and ebselen but not nifedipine protected cerebellar granule neurons against 4hydroxynonenal-induced neuronal death. Neurosci Res. 57:220-92007; 2006. https://doi.org/10.1016/j.neures.2006.10.011

[71] Larroque-Cardoso, P.; Camaré, C.; Nadal-Wollbold, F.; Grazide, M.-H.; Pucelle, M.; 
Garoby-Salom, S.; Bogdanowicz, P.; Josse, G.; Schmitt, A.-M.; Uchida, K.; Zarkovic, K.; Salvayre, R.; Nègre-Salvayre, A. Elastin Modification by 4-Hydroxynonenal in Hairless Mice Exposed to UV-A. Role in Photoaging and Actinic Elastosis. J. Invest. Dermatol. 135: 1873ї 1881; 2015. https://doi.org/10.1038/jid.2015.84

[72] Barrera, G.; Pizzimenti, S.; Ciamporcero, E.S.; Daga, M.; Ullio, C.; Arcaro, A.; Cetrangolo, G.P.; Ferretti, C.; Dianzani, C.; Lepore, A.; Gentile, F. Role of 4-hydroxynonenal-protein adducts in human diseases. Antioxid. Redox Signal. 22: 1681 ï 1702; 2015. https://doi.org/10.1089/ars.2014.6166

[73] Neely, M.D.; Zimmerman, L.; Picklo, M.J.; Ou, J.J.; Morales, C.R.; Montine, K.S.; Amaranth, V.; Montine, T.J. Congeners of N(alpha)-acetyl-L-cysteine but not aminoguanidine act as neuroprotectants from the lipid peroxidation product 4-hydroxy-2-nonenal. Free Radic. Biol. Med. 29: $10281 \ddot{1}$ 1036; 2000. 
A

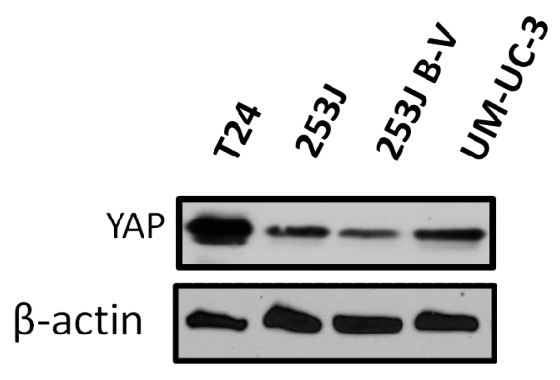

B

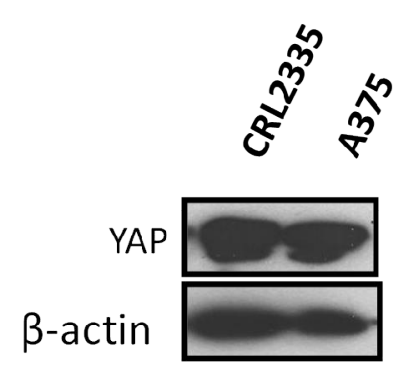

\section{Figure 1 Supplementary data}

Figure S1. YAP basal protein expression in cancer cells. Panel A: WB analysis of basal YAP expression in four human bladder cancer cells, T24, 253J, 253J B-V, and UM-UC-3. Equal protein loading was confirmed by exposure of the membranes to the anti-6-actin antibody. Panel B: WB analysis of basal YAP expression in CRL2335 breast and A375 melanoma cancer cells. Equal protein loading was confirmed by exposure of the membranes to the anti- 6 -actin antibody. 